\title{
'GOD AT WORK': ENGAGING CENTRAL AND INCOMPATIBLE INSTITUTIONAL LOGICS THROUGH ELASTIC HYBRIDITY
}

\author{
Accepted for publication in the \\ Academy of Management Journal
}

\author{
Ali Aslan Gümüsay \\ University of Hamburg, Germany \\ WU Vienna University of Economics and Business, Austria \\ Ali.Guemuesay@uni-hamburg.de \\ Michael Smets \\ Saïd Business School, University of Oxford \\ Michael.Smets@sbs.ox.ac.uk \\ Timothy Morris \\ Saïd Business School, University of Oxford \\ Tim.Morris@sbs.ox.ac.uk
}

Keywords: Hybrid Organizations, Institutional Complexity, Institutional Logics, Institutional Theory, Paradox, Purpose, Resilience

Acknowledgments: We gratefully acknowledge valuable comments on earlier versions of the manuscript from Daniel Geiger, Marc Ventresca, Renate Meyer, Royston Greenwood, Sally Maitlis, Sue Dopson, and Tom Lawrence as well as colleagues at the Academy of Management, the Austrian Early Scholars Workshop, and the European Group for Organizational Studies. We acknowledge financial and institutional support from the Avicenna Foundation, the German Academic Exchange Service (DAAD), Saïd Business School, WU Vienna, and the University of Hamburg. We also would like to express our immense appreciation to KT Bank for welcoming us in their midst. Finally, we want to thank associate editor, Elaine Hollensbe, and three anonymous reviewers, whose comments have greatly benefited the article. 


\title{
'GOD AT WORK': ENGAGING CENTRAL AND INCOMPATIBLE INSTITUTIONAL LOGICS THROUGH ELASTIC HYBRIDITY
}

\begin{abstract}
Based on a 24-month ethnographic case study of the opening of the first Islamic bank in Germany, we make three contributions to the institutional theory literature: First, we outline polysemy and polyphony as mechanisms that dynamically engage conflicting logics through an organizational-individual interplay. Borrowing from paradox theory, we explain how hybrids can empower individuals to fluidly separate and integrate logics when neither structural compartmentalizing nor organizational blending are feasible because management cannot prescribe a specific balance of logics. Second, we explain the state of elastic hybridity, constituted through the recursive, multi-level relationship between polysemy and polyphony. Elastic hybrids maintain unity in diversity. They are capable of institutionally bending without organizationally breaking and thus enable individuals to practice more of their personal convictions at work while still experiencing a sense of shared organizational purpose. Third, we show how contested hybrids can be made to last. By dynamically making logics either less central or more compatible, elastic hybrids become less conflict-prone and more resilient without permanently becoming more aligned or estranged.
\end{abstract}




\section{INTRODUCTION}

A growing number of organizations seek new solutions to societal challenges by consciously straddling competing expectations and 'logics' (Greenwood, Raynard, Kodeih, Micelotta, \& Lounsbury, 2011). Exemplars of such hybrids include community banks, social enterprises, public-private partnerships and healthcare organizations (Almandoz, 2012; Battilana \& Lee, 2014; Jay, 2013; Reay \& Hinings, 2009). They seek to deliver 'the best of both worlds', such as profits and social impact, by intentionally incorporating elements which "seem logical in isolation but absurd and irrational when appearing simultaneously" (Lewis, 2000: 760). In doing so, they embrace paradoxical tensions other organizations seek to minimize.

Prior literature suggests that hybrids address tensions in one of two ways: They either decrease the centrality of competing logics by structurally separating their enactments in dedicated compartments (Jarzabkowski, Matthiesen, \& Van de Ven, 2009; Kraatz \& Block, 2008; Reay \& Hinings, 2009), or they decrease their incompatibility by blending them in new, synthetic prescriptions, practices or arrangements (Battilana \& Dorado, 2010; Dalpiaz, Rindova, \& Ravasi, 2016; Tracey, Phillips, \& Jarvis, 2011). However, contested hybrids in which coexisting logics are both central and incompatible, create heightened levels of conflict (Besharov \& Smith, 2014). They pose conceptual challenges to both alternatives and their underlying assumptions. On the one hand, structural separation assumes limited interdependence and employees' acceptance of the marginalization of some of their institutional commitments. These conditions may exist where new prescriptions enter an organization (Suddaby \& Greenwood, 2005) or they constitute a "minority logic" (Durand \& Jourdan, 2012), but not where both logics are central to the organization and core to staff convictions. In these instances, compartmentalizing poses the risk of leaving the organization and its staff estranged (Besharov \& Smith, 2014). On the other hand, blending assumes that coexisting logics are sufficiently compatible to align a hybrid around shared goals (Townley, 2002). Alternatively, logic incompatibility can be overcome by hiring staff with no prior 
commitment to either logic (Battilana \& Dorado, 2010) or sufficient cognitive flexibility to develop new, synthetic practices (Smets, Morris, \& Greenwood, 2012). This, however, may be unrealistic when the organization is built on strong convictions, organizational members insist on the incompatibility of their respective beliefs, and resist blending and compromise. The latter also applies when organizations "selectively couple" different organizational elements that resonate with different audiences (Pache \& Santos, 2013) as the combination structurally cements a balance of logics which individual staff may contest.

In sum, existing approaches to managing hybridity focus on solutions that are organizational, structural and static. They manage institutional tensions on behalf of employees. Yet, where competing logics are incompatible and central to both the organization and the fundamental beliefs of its employees, it is impractical for an organization to prescribe how individuals manage them. Attempting to strike a uniform permanent balance between conflicting beliefs, such as individuals' religious faith, breeds the level of conflict which Besharov and Smith (2014) associate with highly contested hybrids. Thus, we have a nascent understanding of how organizational leaders may dynamically balance competing demands (Smith, 2014; Smith \& Besharov, 2018), and how individuals may strike different, situated balances (Smets, Jarzabkowski, Burke, \& Spee, 2015). However, we do not currently understand how organizations create the conditions for frontline employees to manage their competing institutional commitments in a more personal, agentic, and dynamic manner so as to allow them to practice more of their fundamental personal beliefs at work. In this paper we therefore zoom in on the interplay between organizational and individual responses to institutional tensions and ask: How can contested hybrid organizations constructively engage central and incompatible logics to reduce conflict and increase organizational resilience?

This question was triggered by a 24-month ethnographic case study of the opening of KT Bank, the first Islamic bank in Germany. KT Bank offered a particularly rich and instructive case, not least because institutional theory has largely neglected the religious logic and non- 
Western religions in particular (Gümüsay, 2017; Tracey, 2012; Tracey, Phillips, \& Lounsbury, 2014). More significantly, contradictory but interdependent demands of religion and market in Islamic banks mean that they persistently engage the kinds of unfolding tensions that define a paradox (Lewis, 2000). These paradoxical tensions are particularly felt at the individual level and in the organizational-individual interplay, in which diverse views about religion, market and their relationship collide. Our case thus sheds light on instances of contested hybrids where both the organization and individual staff confront paradoxical prescriptions, and established approaches to decrease the centrality or incompatibility of logics fail.

Drawing on this instructive case, our study makes three contributions to the literature. First, we derive two novel mechanisms to engage conflicting institutional logics: polysemy and polyphony. We define polysemy as an organization's judicious use of concepts, words, artifacts or images that simultaneously support multiple meanings. It empowers staff to balance competing logics personally and dynamically. We define polyphony as an individual's judicious use of time, place and/or languages to enable simultaneous, but separate enactments of those competing logics. It is through their organizational-individual interplay that organizations create the conditions for staff to manage their own institutional tensions and to engage competing logics in a more personal, behavioral and dynamic fashion. Theorizing the recursive interplay between organizations making space and staff taking space for competing logics contrasts models of top-down managerial action (Smith \& Besharov, 2018) and highlights the role of frontline staff in the management of institutional complexity. Doing so addresses calls for multi-level explanations of institutional dynamics (Powell \& Colyvas, 2008) and richer explanations of "how individuals effectively live within a dynamic state of balance" (Schad, Lewis, Raisch, \& Smith, 2016: 38).

Second, we develop the concept of elastic hybridity. We define this concept as constituted through the recursive relationship between polysemy and polyphony. It captures a hybrid 
organization's ability to maintain unity in diversity by empowering staff to personally and dynamically engage competing logics, in particular when these are central and incompatible. This multi-level concept thus complements existing notions of hybrids structurally fixing a balance or synthesis of competing demands (Greenwood et al., 2011) or constraining their enactment through managerially-imposed "guardrails" (Smith \& Besharov, 2018). It enriches current accounts of how organizations and individuals handle "persistent contradiction between interdependent elements" (Schad et al., 2016: 10) by moving away from either/or responses and towards both/and engagement. Metaphorically speaking, it renders the hybrid capable of institutionally bending, without organizationally breaking.

Third, we explain how elastic hybridity can make contested organizations less conflict-prone. We do so by dynamizing Besharov and Smith's (2014) framework and elucidating how the most conflict-prone instances of institutional complexity can be accommodated. We argue that polysemy and polyphony dampen conflict between central, incompatible logics by making and taking spaces. In so doing, elastic hybridity flexibly - instead of structurally renders competing logics more compatible (polysemy) or less central (polyphony) while they remain contested. This more dynamic and multi-level form of balancing may thus reduce conflict and make organizations more resilient against demise, fragmentation or paralysis. For those working in hybrids, elasticity empowers them to practice more of their ideals at work and still experience a compelling sense of shared organizational purpose.

In the next section we outline the theoretical context of our arguments. We then describe our research methods, research context and our case study of KT Bank's founding. In our discussion section we develop the aforementioned contributions and finally conclude.

\section{THEORETICAL CONTEXT}

\section{Institutional Logics: Market and Religion}

Institutional logics constitute the "organizing principles" (Friedland \& Alford, 1991: 248) by which organizations and individuals in different domains of society "organize time and space, 
and provide meaning to their social reality" (Thornton \& Ocasio, 1999: 804). They prescribe what constitutes legitimate ends to pursue and acceptable means to do so (Pache \& Santos, 2010). Violating these prescriptions risks social ostracism (D’Aunno, Sutton, \& Price, 1991), as well as push-back from disapproving organizational members (Glynn, 2000). Logics of community, corporation, family, market, religion, state, and profession jointly constitute the "master principles of society" (Thornton, 2004: 70) and, governing different domains of social life, are "mutually dependent, yet also contradictory" (Friedland \& Alford, 1991: 250). Management scholars have primarily engaged the logic of the market. Here, the accepted goal is increasing share price (Thornton, Ocasio, \& Lounsbury, 2012). Behavior is governed by "profit-maximizing objectives and a self-interested, individualistic, and arm's-length ethos" (Almandoz, 2012: 1382). Consequently, banks are investment vehicles to optimize earnings, governed by sector-specific enactments cast as a 'banking' (Marquis \& Lounsbury, 2007) or 'financial' logic (Almandoz, 2014). What matters is the short-term gain in the here and now.

In contrast, few scholars have studied religion from an institutional perspective. This is perplexing given that 'beliefs' are central to both Thornton and Ocasio's (1999) definition of institutional logics and to their societal role to "make life meaningful" (Friedland \& Alford, 1991: 249). Those who have studied religion, have typically focused on Christian organizations such as churches (Creed, DeJordy, \& Lok, 2010; Nelson, 1989, 1993), religious orders (Quattrone, 2015) or religious movements (Tracey, 2016). Their legitimacy arises from the sacredness of rituals and traditions and it is social or moral rather than instrumental in nature (Peifer, 2014). Norms flow from divine commandments, as codified in religious scriptures and practiced by believers (Thornton et al., 2012). They postulate selflessness and salvation, not self-interest and profit. What matters is the long-term 'return' in the Hereafter.

Logics of market and religion may prescribe incompatible means and ends. "The temple is holy because it is not for sale", Pound (1996: Canto 97) succinctly put it and the biblical 
account of Jesus expelling the tradesmen from the temple provides an evocative image of this incommensurability. Following Matthew 6:24, serving both 'God' and 'Mammon' is commonly seen as "serving two masters". Accordingly, DeJordy and colleagues (2014: 301) adopt this image to illustrate the contradictions between logics of faith and inquiry at a religious university. Institutionalists have contrasted logics of market and religion by juxtaposing Christian norms with Western capitalism (Friedland \& Alford, 1991; Thornton et al., 2012). However, similar tensions afflict non-Western religions and faith-based economic systems (Weber, 1920). Boone and Özcan (2016), for instance, show how Islamic banks in Turkey were contested, despite operating in a religiously embedded market.

Incompatibilities intensify when religious norms meet market expectations from different institutional systems (Gümüsay, 2017), even in seemingly mundane instances, such as the insistence on professional over religious attire at work (Purchase, Ellis, Mallett, \& Theingi, 2018). They further escalate around an organization's core; its purpose, products and practices. For instance, Islamic banking explicitly bans the payment of interest (Quran, 2:275), a cornerstone of conventional Western banking practice. Likewise, it prohibits speculation and risk trading, as in conventional derivatives (Ayub, 2007: 43-64). Trade with conventional banks that speculate and use interest is therefore also problematic (Hayat \& Malik, 2014: 26). Accordingly, Thornton et al. (2012: 63) conclude that "the contemporary case of Islamic religion remains in conflict with market principles”.

These incompatibilities are particularly likely to resist collective efforts for resolution because religion may constitute an individual's "unconditional, infinite and ultimate concern" (Tillich, 1957: 8). These concerns are less malleable, open to compromise, or easily accommodated when confronting alternative prescriptions. As Pache and Santos (2010) note, conflict over "ends" is bound to be more intense than conflict over "means"; even more so, where the end at stake is 'ultimate'. In the words of DeJordy and colleagues (2014: 331-332), religion is a "greedy" logic that calls for "holistic and comprehensive commitment". Violating its 
prescriptions evokes particularly strong emotional reactions, as their carriers reject the relativization of their values and "convert all issues into expressions of absolute moral principles" (Friedland \& Alford, 1991: 249). The combination of low compatibility, low malleability and risk of heated conflict has made religion socially and scientifically a taboo topic (Chan-Serafin, Brief, \& George, 2013). Yet, it is this very combination which makes studies of the interaction between religion and market significant (Tracey, 2012: 119).

Examples abound of debates whether logics of markets and religion are complementary or conflicting (Gümüsay, 2018). Notably, Weber's (1904) Protestant work ethic portrays commercial success as a sign of divine blessing, attained through hard work. Megachurches employ commercial elements in their religious practice. Islamic banks have long existed in predominantly Muslim countries. All of these efforts have sparked controversy, however. Weber's arguments have been rejected for "absence of empirical support” (Iannaccone, 1998: 1474). Megachurches face criticism for "a consumerist approach to theology that is absent of the rigor and sacrifice often demanded by traditional churches" (Washington, Van Buren III, \& Patterson, 2014: 194), and Islamic banks have been controversial even in Muslim countries (Boone \& Özcan, 2016). As the contested existence of these organization shows, some individuals are able to balance these competing values for themselves while others resent the respective balances they strike. Hence, there is nascent evidence of Muslim entrepreneurs fusing work and worship into "wor(k)ship" to fashion a hybrid personal identity for themselves (Gümüsay, 2015: 202; see also Essers \& Benschop, 2007), but a single collective organizational identity that hybridizes religion is problematic. This point reinforces the notion of faith as a personal matter and the paradox that "individually coherent propositions can collectively contradict one another when rigorously pursued to their logical conclusion" (Chia \& Najak, 2017: 130). This means that not only should an Islamic bank reveal incompatibilities between prescriptions of market and religion, especially when based in a non-Muslim country, but also between competing constructions of their compatibility. 


\section{Organizational Hybridity: Separation and Integration}

Hybrid organizations are, by their very nature, "the structural embodiment or incarnation of multiple logics" and thereby "multiple things to multiple people" (Kraatz \& Block, 2008: 244). The key paradox, therefore, is to both separate opposing factions to reduce conflict and connect them to realize potential synergies (Jay, 2013; Smets et al., 2015; Smith \& Tracey, 2016). Yet, building on longstanding traditions in contingency theory (Lawrence \& Lorsch, 1967), institutional scholars have mainly focused on managerial interventions which prioritize either the permanent separation of competing logics in structural compartments or their integration in blended hybrids (Greenwood et al., 2011). We compare these approaches, build on nascent efforts to fluidly engage competing logics as the paradox literature would suggest (Schad et al., 2016; Smith \& Besharov, 2018; Smith \& Lewis, 2011), and argue that their underlying theoretical conditions are unlikely to be met in contested hybrids.

"Structural hybridity", the separation of competing logics in organizational units, has traditionally taken center-stage given institutionalists' preoccupation with "incompatible prescriptions from multiple institutional logics" (Greenwood et al., 2011: 317). These incompatibilities produce "antagonisms in the organizational arrangements required" and conflicts between factions representing competing logics (Pache \& Santos, 2010: 457). To reduce conflict, compartmentalization "creates separate sets of guiding principles and demarcates the domain of application of each" (Dalpiaz et al., 2016: 368). Reminiscent of Lawrence and Lorsch's (1967) structural differentiation, or Poole and Van de Ven's (1989) spatial "splitting", such demarcation creates permanent structural units which follow a different logic and engage different audiences. Examples include collegiate athletics departments (Kraatz \& Block, 2008), service lines in multidisciplinary service firms (Suddaby \& Greenwood, 2005), or infrastructure and retail units in utilities companies (Jarzabkowski et al., 2009). Similarly, in the case of "selective coupling" organizations incorporate intact structural elements, which each resonate with a particular logic (Pache \& Santos, 2013). 
Permanently compartmentalizing staff who enact different logics protects them "from the tension, frustration and lost faith that follow when enactments of one logic are observed by representatives of another logic" (Smets et al., 2015: 959). The downside of separation, however, is the risk that compartments become "cellular, self-sealing, and institutionalized" (Ferlie, Fitzgerald, Wood, \& Hawkins, 2005: 129) or estranged (Besharov \& Smith, 2014). It also rests on two implicit yet strong assumptions. First, staff pre-empt fragmentation by connecting compartments through "formal and informal collaborative relationships" (Reay \& Hinings, 2009: 643). This "requires actors to set aside their current beliefs" (Dalpiaz et al., 2016: 372) and potentially compromise in the spirit of collaboration. However, individuals may refuse or struggle to do so, if what is at stake is an "ultimate concern" to them (Tillich, 1957: 8). Second, empirical accounts of compartmentalizing and selective coupling showcase situations in which an institutional imprint gives one logic salience over another (Pache \& Santos, 2013), or a new logic enters an organization at the periphery, such as in the managerialization of healthcare (Reay \& Hinings, 2009). In these cases, one logic is typically “dominant" over a "minority", which is marginalized in its compartment (Durand \& Jourdan, 2012). In particular, this is not possible when logics form a paradoxical relationship that leads to persistent interdependencies that make them not only oppositional but also mutually constitutive and inseparable (Schad et al., 2016), like in an Islamic bank. The theoretical conditions for compartmentalizing are therefore typical of estranged hybrids, but not of highly contested ones in which both logics are central and incompatible (Besharov \& Smith, 2014).

Blended hybrids prioritize integration over separation. They layer activities informed by competing logics into new practices, synthesize new prescriptions or fashion novel organizational forms. For instance, the social enterprise Aspire combined charitable and commercial retail activities to combat homelessness (Tracey et al., 2011). Smets and colleagues (2012) found English and German banking lawyers to layer previously compartmentalized work practices in seamless cross-border services. In the extreme, blended 
hybrids forge a hybrid logic which downplays incompatibilities between its constituent elements (Battilana \& Dorado, 2010). For example, Dalpiaz and colleagues (2016) show how designers of Alessi's household goods successfully blend logics of industry and art "by reinterpreting them to render them more compatible" and exploiting "the flexibility of categorical requirements" (2016: 369-371).

Such flexibility and ability to reinterpret are far from given. Yet, they are implicitly assumed in current approaches to blended hybrids. On the one hand, flexibility and openness to reinterpretation presuppose a certain level of compatibility or alignment between logics. Smets and colleagues' (2012: 883) lawyers coalesced around their common professional ethos as lawyers and the shared goal of "getting the deal done". Childcare workers in Binder's (2007) study agreed on the central goal of child welfare, even if they approached it from state and professional logics, respectively. Hybrids can blend logics through "structured interaction between collaboration and formalization", but only when collaborating across the organizational core and periphery, where staff can discover space for flexibility and compromise (Ramus, Vaccaro, \& Brusoni, 2017: 1253). These situations are characteristic of aligned hybrids in which coexisting logics may both be central, but at least to some extent compatible or open to compromise.

On the other hand, where competing logics are incompatible, the ability and willingness to reinterpret presupposes a level of cognitive, communicative, and normative flexibility which is rare, given how prior embeddedness imprints and cognitively constrains actors (Almandoz, 2014). Arguably, successful blending depends on a strong organizational identity that outweighs individuals' attachments to field-level logics (Greenwood et al., 2011). That is why Battilana and Dorado (2010) conclude that blended hybrids must recruit staff with no prior attachment to either logic and then socialize them in the organization's own hybrid identity. Greenwood and colleagues (2011: 353) therefore argue that "zero prior experience with a logic is a prerequisite for blended hybridization." Alternatively, elite status, as in corporate 
law firms, can buffer staff from institutional demands and develop them into "cosmopolitans" with greater cognitive flexibility and ability to hybridize (Smets et al., 2012: 886).

Nonetheless, these approaches are unlikely to support hybrids where blending straddles incompatible convictions and values that are deeply held, such as religious beliefs or professional ethos. Institutional buffering is particularly difficult where values are anchored in a field-level community, which monitors and reinforces individuals' institutional commitments. Likewise, recruiting candidates with 'no prior commitment' or a high level of flexibility seems impractical when broad normative convictions are at stake. For instance, in the case of the religious logic, hybrids cannot screen job candidates for a prior institutional imprint, nor feasibly socialize them into a different religious conviction, nor can they expect individuals to be as (cognitively) flexible with their religious beliefs as with their work practices. Arguably, under these conditions blended hybrids are likely to fail for one of two reasons: First, they risk "slippage" (Battilana \& Dorado, 2010; Smets et al., 2015) insofar as the organization over-prioritizes one logic and risks a loss of legitimacy. Second, the continuous collaboration of staff carrying different logics re-creates the tensions compartmentalizing seeks to address (Besharov, 2014; Jay, 2013). In sum, blending works for aligned hybrids, but is being challenged by contested hybrids incorporating deeply held, personal normative commitments.

Common to both compartmentalizing and blending approaches is their organizational, structural, and static nature. The organization structurally cements a specific balance of logics through managerial intervention, be that the installation of organizational units (Jarzabkowski et al., 2009), the recruitment of particular staff (Battilana \& Dorado, 2010), or the selection of certain organizational elements to resonate with a specific logic (Pache \& Santos, 2013). Notably, even solutions that sustain hybrids through "structured flexibility" rely on organizational "guardrails" that bound managers' experimentation with competing logics (Smith \& Besharov, 2018: 27). The persistent focus on managerial and structural responses to 
incompatibilities diverts attention away from the people who inhabit them, their personal efforts to make meaning within them, and the interplay between organizational and individual efforts to sustain hybridity.

\section{Emerging conversations in institutional theory}

To address these limitations, it appears fruitful to leverage three emerging conversations in institutional theory: The nascent dialogue with paradox scholars, studies of space and time as more flexible ways of engaging competing logics and meaning making through communication. Paradox thinking is an intuitive place to look for a remedy, not least because Besharov and Smith (2014) highlight that clashes of 'central' yet 'incompatible' logics are the most conflict-prone instances of hybridity, because they pose particularly paradoxical challenges (Battilana, Sengul, Pache, \& Model, 2015; Jay, 2013). More profoundly, paradox scholars are attuned to the dynamic balancing of competing demands (Smith, 2014; Smith \& Lewis, 2011). They foreground the continuous engagement and mutual constitution of competing logics over the definitive resolution of conflicts between them (Smith \& Tracey, 2016). In doing so, they also note how the separation and integration of competing demands may happen at the organizational (Andriopoulos \& Lewis, 2009; Smith \& Besharov, 2018), but also the individual level (Besharov, 2014; Smets et al., 2015). We reiterate calls from paradox scholars to explore tensions across multiple levels and sources (Putnam et al., 2016) and specifically attend to the "relationships within paradoxes, individual approaches, and dynamics" (Schad et al., 2016: 6, emphasis in original). In particular, we address criticisms that institutional and paradox theory "often focus on the nature of the tensions but offer less insight into how organizational members differentially experience them" (Smith \& Tracey, 2016: 461) and respond to related calls to explore how their approaches to paradox "aggregate to higher-level organizational responses" (Schad et al., 2016: 42). We do so by showing how members' differential experience of institutional demands and the sum of their individual responses accrue to elastic hybridity for the organization. 
The literature has recently hinted that time and space help organize logics just as much as logics organize time and space. Some institutional scholars started to pay attention to the times (Granqvist \& Gustafsson, 2016; Raaijmakers, Vermeulen, Meeus, \& Zietsma, 2015) and spaces (Battilana et al., 2015; Kellogg, 2009; Preminger \& Drori, 2016) actors use to make sense, suspend conflict, and manage competing institutional logics. In doing so, they point us to the need to understand better how individuals use and create organizational spaces to make sense of their organizational existence.

Finally, while Cornelissen, Durand, Fiss, Lammers, and Vaara (2015: 11) have recognized communication as "formative of institutional reality", the role of micro-level communication in the co-construction of meaning has received scant attention to date (Tracey, 2016). In fact, so has the use of language more broadly, be it verbal or visual, single language or multiple languages. We thus take seriously Suddaby's (2010: 17) call 'to analyze the role of language in institutional processes and effects", and the proposal by Cornelissen and colleagues (2015: 21) to focus on multilevel studies at the intersection of communication and institutional logics.

We argue that shifting attention from organizational structures to the people who inhabit them and their organization of space, time, and language allows us to advance against Kraatz and Block's (2008: 244) puzzle of how hybrids can be "multiple things to multiple people". In summary, we address three blind spots which currently circumscribe the institutional hybridity literature: The relative neglect of (a) the most conflict-prone settings where coexisting logics are both central and incompatible, (b) organizational responses to hybridity challenges other than reducing centrality through compartmentalizing or incompatibility through blending, and (c) the multi-level interplay between individuals and the organizational structures they create, inhabit and provide meaning for. Addressing these concerns responds to repeated calls to transcend the dichotomy of logics being compatible or conflicting, separated or integrated, and to "delve deeper into the dynamic patterns of complexity" 
(Greenwood et al., 2011: 334). It uncovers multi-level paradoxical both/and responses that engage competing demands to increase the resilience of highly contested hybrids.

\section{METHODS}

We addressed our research question with a 24-month ethnographic case study of KT Bank, the first Islamic bank in Germany and the Eurozone. KT Bank is an "unusually revelatory" case (Eisenhardt \& Graebner, 2007: 27) for three reasons. First, an Islamic bank is a "highly contested" hybrid in Besharov and Smith's (2014) typology, as its constituent logics are both central and incompatible: Religious prescriptions of the Sharia go directly against taken-forgranted banking practices (Ayub, 2007). We know very little about how this most conflictprone form of hybridity is made to last. Second, these incompatibilities are especially vivid in KT Bank as Germany is a predominantly non-Muslim market. While Islamic banks have been contested even in Muslim-majority countries (Boone and Özcan, 2016), accommodating Islamic banking in a context such as Germany accentuates contradictions in discourse and practice and should prove particularly challenging (Gümüsay, 2017). Therefore, any insights are of theoretical significance to institutional theorists and paradox scholars interested in how organizations constructively engage demands that are mutually constitutive, yet persistently incompatible. Third, Islamic retail banking was "at a fairly embryonic stage" in Europe (Di Mauro et al., 2013: 9) and non-existent in Germany. KT Bank therefore had no established template for its structures and practices. This provided us with a unique opportunity to study in real time how an organization engaged conflicting logics in its founding process. Metaphorically, the bank and its staff were weaving the threads of conflicting logics into the fabric of a new organization in front of our eyes. To capture this process in situ, we chose an ethnographic case study as the most appropriate research design (Zilber, 2016).

\section{Data Collection}

We relied on multiple data sources as summarized in Table 1: observations, interviews, and documentary evidence, labeled 'obs', 'int', and 'doc', respectively. 
Insert Table 1 about here

Ethnographic Observation. To 'be there' when the bank and its people engaged institutional incompatibilities in its founding process, the first author negotiated deep access to the bank's full range of activities, documents, and people. He did so by connecting with one of KT Bank's senior managers, a peer in the German Muslim business community and himself a former doctoral student. For him, the presence of an independent observer resonated with the bank's commitment to transparency and his personal academic interests. A broad framing to examine what it takes to set up an Islamic bank in Germany offered KT Bank staff what Rossman and Rallis (2003: 154) call a "partial explanation" of the observer's role: It explained his presence, but not the specific purpose of his study. It afforded him the role of "participant-as-observer" (Gold, 1958: 220) and the opportunity to observe both formal and informal settings, which is crucial for understanding how incompatible logics are negotiated.

As a German-born Muslim of Turkish origin, the first author was uniquely placed to fill this role and immerse himself in the professional and communal life of the bank. He could freely move in commercial and religious spaces, talk to staff in their mother tongue, and participate in the religious and social activities of the firm. Simultaneously, his professional background in consulting and entrepreneurship meant he understood KT Bank's market context so that he was equally sensitive to both logics at play. Conscious that informants often cast a participant-as-observer "as more of a colleague than he is capable of being" (Gold, 1958: 221) he carefully limited participation in professional work to instances of 'helping out' to build rapport, for example by proofreading documents. In conversation, he chose to be "truthful but vague" (Taylor \& Bogdan, 1984: 25), which was aided by his sponsor's sensitivity to the requirements of academic research and agreement to embargo feedback until the end of the project. 
In total, the first author spent sixty days in the field. During this time, he attended over one hundred formal meetings - from executive meetings to more mundane design meetings about the bank's religious facilities. He shared offices with staff, observed their everyday work, and had many informal encounters around work as well as prayers. These unstructured moments showed prescriptions of market and religion 'in action' and revealed how participants explained their meanings to each other, rather than to him. Finally, he attended meetings with external stakeholders, potential customers and service providers, bank presentations and fieldlevel conferences on Islamic Finance in Germany.

Throughout, he recorded observations in a research diary. Observation notes documented each interaction episode, its organizational context, information shared, and emotions evoked. To collect a continuous stream of data, the first author followed conversations at the bank via email, telephone or conference calls in between site visits. He thus ensured his presence during events of commercial or religious significance, such as the first client presentations or the fast of Ramadan, as Figure 1 illustrates. Iterating between deep immersion and retreat from the field afforded him longer reflective breaks, which he used to enrich his notes and debrief his 'outsider' co-authors. These exchanges served two purposes. They created surrogate immersion for the 'outsiders' and artificial distance for the 'insider' (Gioia, Corley, \& Hamilton, 2013). While the first author's language ability and cultural sensitivity were essential to 'blend in', it was the 'outsider' co-authors' role to question his data and re-affirm his role as "the stranger" before re-entering the field (Gold, 1958: 221).

Insert Figure 1 about here

Interviews. We used semi-structured interviews to follow up on questions raised by observations (Pratt, Rockmann, \& Kaufmann, 2006). We uncovered their deeper meanings by prompting reflections in the privacy of the interview setting. In combination with the ability to interview respondents in their mother tongue, this produced insights into deeply held 
personal values and beliefs. Respondents often intuitively referred to the underlying values driving their observable actions. For instance, when we asked a manager why he joined KT Bank, he expressed his desire to build an organization where his children could bank in accordance with their faith. Interviews started with questions about the founding process, its milestones and challenges. They then explored the role of religion in KT Bank and Islamic banking more generally as well as the interactions between the bank and external stakeholders such as regulators. Finally, they zoomed in on the relationship between banking and religion, what attracted individuals to the bank and how it accommodated their personal convictions.

We conducted a total of 73 interviews, lasting an average of 60 minutes each. These spread over the entire 24 months of fieldwork and covered all key actors in the bank, from executive level to frontline employees. Eight of the most central people, including the CEO and Head of (Islamic) Compliance, were interviewed both at the beginning and end of the fieldwork to ask about emerging themes and to review the founding process. We also interviewed field-level actors to capture the institutional context in which KT Bank operated.

Documentary Evidence. The first author was given access to the bank's intranet in which documents were stored and shared. These included company statements, handbooks, guidelines, notes, pictures, presentations, reports, and videos, which were valuable for comparing company policy and practice. Status reports, meeting minutes and committee documents as well as different versions of draft documents proved particularly valuable to trace key decisions and challenges in the founding process. They documented the gradual codification of market and religious logics in the language and symbols of the bank. This process was especially useful for revealing 'what could have been', i.e., plans that were deemed too contentious and eventually abandoned. We cast the net for our data collection deliberately wide and some seemingly trivial documents only revealed their relevance later. For instance, architectural designs showed how much thought KT Bank put into its ritual washing facilities, a fact numerous respondents later highlighted as significant. We also 
collected field-level documents such as conference reports, newspaper articles, and legal texts to contextualize our account of KT Bank both in the structures of the German financial market and the wider world of Islamic banking. As we reached theoretical saturation and new materials began to confirm our insights, we ended data collection with the bank opening; a natural cut-off point in July 2015.

\section{Data Analysis}

Our data analysis entailed a series of iterative stages following established procedures for working with qualitative data (Corley \& Gioia, 2004). We began our formal data analysis by open coding bits of text as either 'religion' or 'market'. For instance, documents mentioned Sharia rules (religion) or the costs of building a novel template for a bank (market). In this phase, we were struck by the frequent need for explanation because the 'insider-author' coded key concepts and communication elements such as the bank's key values, logo and slogan in ways the 'outsider-authors' did not initially see. Through these discussions, we discovered that KT Bank used ambiguity and vagueness to grant people the flexibility to make the bank 'theirs'. Religiously minded audiences would see symbols and slogans as having a religious connotation, while others would not. Thus, rather than the bank imposing a fixed balance of religion and market, its deliberate vagueness afforded everyone flexibility to comprehend the venture from their viewpoint and strike a personal balance. We differentiated conceptual flexibility regarding key ideas such as Islamic banking and Islamic compliance from presentational flexibility of artifacts and statements. Both are second-order themes in our theoretical framework in Figure 2.

Insert Figure 2 about here

In parallel, we openly coded the full repertoire of practices observed during ethnographic fieldwork to systematically capture what was going on (Locke, 2001). We identified activities such as project status presentations or supplier negotiations as 'work' and activities such as 
prayers or ablutions as 'religion'. We then cross-coded these activities to the various physical places in which they happened, such as the office, meeting room, prayer room, or mosque. We then did the same for the temporal structures of the working day, to identify not just what happened where, but also when. For instance, during Ramadan, many discussions among people fasting occurred in the prayer room during lunchtime and the late evening in the office. Throughout these coding and cross-coding steps, we retained data in its original language. With the second co-author also fluent in German and English this worked well, but the first author had to translate Turkish and Arabic excerpts. It was through this process that the 'outsider' co-authors noticed how many sentences requiring translation articulated religious themes. For instance, one interviewee explained: “When I start a task, I first say: In the name of God, the most beneficent, the most merciful, God help me." In the original interview, however, he started the description in German, but then switched language to authentically articulate the religious formula in Arabic and Turkish: "Wenn ich eine Aufgabe beginne, dann sage ich erst einmal [German] Bismillahirrahmanirrahim [Arabic]; Allahım, sen bana yardımc1 ol" [Turkish]. It was thus through the first-hand experience of language barriers in the research team that we stumbled upon the role of language in separating communities. It allowed us to capture what would otherwise have been an "uncodifiable creative leap" (Langley, 1999: 691), and completed our picture of what happens, where, when, and in what language. As our data showed that 'religion' and 'work' each were more prevalent in specific places, times and languages, we interpreted these as means of taking different spaces for separate conversations to moderate conflict between competing expectations of the bank. Thus, we distilled spatial, temporal, and multilingual dynamics as second-order themes in our process of gradual abstraction.

The interpretive flexibility afforded by the organization allowed individuals to find a personal balance between competing logics. Simultaneously, individuals flexibly assigned their enactments to different places, times and languages and dampened their conflict with other 
staff who had struck a different personal balance. Hence, our second-order themes spoke to the issue of flexibility. The first set of themes (conceptual and presentational) addressed it from the perspective of the organization, while the second set (spatial, temporal, multilingual) did so from the stance of the individual employee.

As we had first discovered this flexibility in the use of multiple languages and the coexistence of multiple voices, we stayed with that image. We borrowed Bakhtin's (1984) notion of polyphony and applied it to organizational hybridity. Further reading in this area led us to Zilber's (2011: 1543) polysemy of signs, which she describes as "their ability to be interpreted in different ways in different contexts". This resonated well with our second-order themes of conceptual and presentational flexibility. We therefore grouped conceptual and presentational dynamics under polysemy, and spatial, temporal and multilingual dynamics under polyphony as aggregate theoretical dimensions. Finally, sensitive to the fact that employees inhabit the structures created by their organization, we surmised that polysemy and polyphony would not coexist independently and explored their relationship. We realized that instances of polysemy and polyphony are mutually reinforcing. They jointly enable enactments of competing institutional logics in the way the organization makes space and individuals take it.

In a subsequent step, we openly coded for where and how KT Bank accommodated diverse views and practices. For instance, there were no restrictions on when and how to use the prayer room. Similarly, we observed that some meetings started with prayers and others did not. We cross-coded these cases as being inclusive of different beliefs and behaviors, as the bank implemented neither sanctions nor restrictive policies. It remained open to various practices. In other instances such as the gala dinner dress code, the bank provided guidelines and even specific materials that offered choice between alternatives. We cross-coded such cases as providing a selection of options, i.e. as being optional. Together, inclusiveness and optionality form elastic hybridity, a coexistence that neither separates nor blends competing 
logics, but allows staff to dynamically and flexibly balance them to make the organization their own. This affords the organization the resilience to institutionally bend, but not organizationally break.

\section{THE CASE STUDY}

We present our findings through a gradual sequence of 'zooming' in and out. We 'zoom in' from the institutional context, both commercial and religious, to the bank's organizational purpose and positioning in this context, to the individuals who personally engage market and religion to embody the bank's hybrid purpose. Finally, we 'zoom out' again to show how the organizational-individual interplay afforded KT Bank the elasticity to accommodate diverse beliefs, values and convictions, avoid fractioning and 'make it to the start line'. These underpin our themes and theoretical dimensions as summarized in Table 2.

Insert Table 2 about here

\section{Institutional Context}

Without an existing organizational template, KT Bank built its purpose and market position from two questions: 'What kind of Islamic bank would the market allow us to be?' and 'What kind of Islamic bank do we want to be?' (obs.). It was thus caught between prescriptions of religion and market and how they were articulated: 'outside-in' by regulators, religious bodies and potential customers, or 'inside-out' by staff with personal convictions and beliefs.

After the financial crisis, German regulators were curious how Islamic banks could fit into the existing field. In 2009 and 2012, the Federal Financial Supervisory Authority hosted two conferences on Islamic Finance, in which representatives from KT Bank actively participated. KT Bank's managers also repeatedly met with regulatory authorities as part of the licensing process. They submitted company documents and responded to formal requests to revise their business model and operations "to ensure that they meet the requirements of the German Banking Act" (int). The primary concern here was the extent to which religious restrictions 
would jeopardize KT Bank's commercial viability. This mattered for the Federal Financial Supervisory Authority's mission to protect customers against the bank's potential misconduct or default. It also mattered to other banks in the field that pool risk to ensure stability. The Auditing Association of German banks submitted over 70 questions on topics such as the business model, compliance, marketing, operations and risk management before they were convinced that KT Bank did not expose them to an undesirable level of risk. The balance of religious observance and commercial viability hence became a central concern for the bank in developing and portraying its hybrid purpose.

To demonstrate commercial viability, KT Bank's holding company started testing the market with a representative office even before applying for a German banking license. Once KT Bank set up its project office, it commissioned a study on viable market segments. It surveyed over 600 potential customers on the "market potential for Islamic Banking" (doc) to develop a more granular understanding of what they expected of an Islamic Bank. New staff also carried these expectations into the bank via their own beliefs.

Bank representatives frequently discussed their evolving strategy with officials of the four largest Muslim organizations in Germany, representing over 2000 mosques, to gain their approval as legitimating stakeholders and their business as potential customers. More formally, the bank's internal Ethics Council consulted an external panel of three prominent Islamic scholars that formed the external Ethics Council to ensure religious compliance. Together they formed a construction that weaved throughout the entire organization, as members of the internal council were at the same time positioned across departments, and the advice given impacted the whole organization from practices, processes to products and structures. Emulating Sharia boards elsewhere, KT Bank originally codified the Ethics Council's authority to sign off its banking proposition. Such power, however, violated German law, which states that ultimate authority and responsibility have to rest with the board 
of directors. In response, KT Bank re-cast the Ethics Council more vaguely as an advisory body:

“The Ethics Council shall advise the Company's governing bodies upon their request on religious and ethical issues and regularly meet for information and consultation purposes. (...) The Ethics Council is not authorized to give instructions to the Company's governing bodies." (doc)

Yet, if the Ethics Council had deemed the bank to lack religious compliance, the repercussions in the field and the firm would have been catastrophic. Senior management was explicit that they would follow its advice. It signaled both market compliance to regulators and religious observance to customers and staff: While the board of directors had de jure authority, advice by the Ethics Council would de facto be followed. In doing so, the bank avoided a clear hierarchy of market and religion in the bank's governance, or an agreed balance of commercial viability and religious observance in the field. Both were clearly central to KT Bank. Yet, despite a favorable institutional climate, they were also incompatible in many ways. In the absence of viable structural solutions to this complexity, what constituted an acceptable balance of market and religion was severely contested inside the bank and among its staff throughout the founding process.

\section{Polysemy - KT Bank Making Space and Finding its Purpose}

Concept. Managerial attempts to clearly define KT Bank's organizational purpose and specific balance of religious and commercial ambitions evoked frustration and skepticism, occasionally even tears of anger. Such conflict flared up even around seemingly trivial issues where they touched deeply-held convictions which people considered central to 'their' vision of the bank. For instance, the bank planned to impose a 'no beard' policy for male staff as a signal of compliance with market conventions of professionalism. Some staff, however, considered it an unacceptable intrusion in their religious expression. Heated debates culminated in one manager storming down the corridor red-faced - and the bank abandoning the policy. We repeatedly heard staff venting their frustration with the direction the bank was 
taking, even threatening to leave. One leaver confided that his decision was triggered by his inability to reconcile personal religious convictions with the bank's strategy.

Management was eager to avoid such departures because staff were important ambassadors for the bank in their respective communities. They had to be personally convinced of the bank's religious compliance and financial soundness. Also, as one manager noted, of those who applied to work at KT Bank, "few bring the right expertise and attitude for Islamic banking at a more senior level" (obs). Those who did combine market skill and religious sensitivity were particularly valued and the bank needed to be sensitive to their convictions. Hence, it prioritized accommodating diverse views to retain valued staff and progress towards its opening. As a result, we noted that remarkably few employees left.

Among those who stayed, we observed how two strikingly divergent views were equally present: One view stressed religious commitment, which seeks to fit the market into religion. This was powerfully impressed upon us in an anecdote from one of the senior executives. He reminisced how he had tried to convince the CEO of KT Bank's holding company of the market potential of an increasingly affluent population of young Muslims in Germany. Visibly moved by the memory, the executive told us how the CEO ignored his point completely, but passionately welcomed the opportunity to help young Muslims to bank in accordance with their faith. For the CEO profit was necessary but not sufficient because religious goals were primary. Rather than being tagged on in a "tick-off box" (int) exercise, religion subsumes everything the bank does "like an umbrella" (int). Proponents of this strong view demanded a full commitment to the spirit of Islamic law and a comprehensive reinvention of banking based on the primacy of Islamic values:

"Islamic banking is not just about the product. It is about values. (...) What is the underlying idea behind Islamic conformity? (...) By this holistic approach, I understand that we do not just abide by strict rules, but go beyond and include sustainability, animal protection, and so on." (int)

By contrast, other managers endorsed religious compliance and rejected any plans to raise ethical standards beyond strict prescriptions. They aimed to fit religion into the market. Using 
the vocabulary of the market, they considered Islamic compliance a "risk", "cost" (obs), or means to unlock the German market. They were keen to start business as soon as possible:

"IIf] the deal is not Halal and religion says: 'don't do it', then KT Bank won't do it. (...) If the Ethics Council says: 'It is Islamic compliant', then that is enough. We then do not need to argue, but to look how to position the product in the market. (...). It is important that it is Islamic Finance compliant, and no more. (...) We're a bank, we need to make money." (int)

This contest between compliance and commitment became particularly heated over a new product proposition, which had initially sparked a lot of excitement (obs): a purchase-specific credit card. Contrary to conventional credit cards, the card would be pre-charged with a specific amount of money for a short period of time, ideally for the purchase of a prespecified item. It would also preclude the purchase from certain product categories such as alcohol and gambling. These narrow specifications complied with the prohibition of interest and specific products. Formally, KT Bank would buy the item on behalf of the customer and then sell it on to them at a small premium through two trades that effectively happened simultaneously, one instantaneously following the other. More profoundly, as one manager argued, the credit card would have in-built Sharia commitments (obs), as it promoted limited spending within the customers' means and discouraged excessive consumption. Such broader commitments, however, sparked resistance from those arguing that "religion has a constraining role and KT Bank has the goal to be profit maximizing" (int). As a result, managers could not agree on a specific balance between compliance and commitment, or values of religion and market. To accommodate these diverse views, they later discussed a different credit card model that would devolve this debate to the customer by obliging them to sign a document in which they committed to adhere to Sharia standards. Through regular monitoring, the bank could reprimand customers and even terminate the business relationship in case of misuse. This proposal highlighted two things: First, the inability to reconcile competing positions on the balance of religious and market demands, as the bank ultimately made space for individual customers to use the credit card for more or less religious purposes. They did not settle on a narrow product definition. Second, numerous meetings ended with 
vague understandings of contentious issues, document sign offs being postponed, or decisions taken "pending approval" (obs). In this case, employees were content with the vague credit card model, where the balance between religion and market was delegated to customers and where practical monitoring and enforcement were left open and under-specified.

We soon realized that this was a recurring pattern: Decisions were regularly postponed or kept deliberately vague. For instance, when the Head of Compliance developed the bank's compliance management standards, he took the market-typical seven pillars of compliance and added "Islamic Finance discussion and concerns" as an eighth column to his excel spreadsheet (doc). He pragmatically avoided any specificity - and conflict - on the interaction between religious and regulatory compliance. This approach prevailed even among the most senior managers, as the first author discovered in a 90-minute meeting with two of them. Both were eager to re-think banking. Yet, they conceded that establishing a consensus over the balance of market and religion for the entire bank - their preferred solution - was simply infeasible at this stage, given how differently individual staff balanced them.

In consequence, KT Bank kept its purpose and strategic positioning wide open right up to its founding. At the gala opening, all four keynote speakers emphasized the religious and market goals of KT Bank, declaring their intent to offer "robust banking principles and ethical values" and distinctiveness in "product range and prices". Most prominently, though, this deliberate vagueness was reflected in the development of KT Bank's articles of association: An early draft of the mission statement specifically heralded KT Bank as "the first provider of Islamic compliant financial products and services in Germany" (doc). The final version, however, painted a blurrier picture, positioning KT Bank as an "ethical bank":

"An ethical bank, KT Bank AG - on the basis of both the religious-ethical canon of values of Islam and universal values - is committed to a sustainable business strategy." (doc)

Presentation. The evolution of the articles of association shows how staff contested not only the bank's purpose, but also its presentation, both externally and internally. 
Throughout the founding process, the bank had to juggle opposing views about the extent to which it should present itself as 'Islamic'. On the one hand, some staff argued "we should position ourselves externally as an Islamic bank. That's a transparent approach, not to try to hide something, but to say: "These are our moral values"' (int). On the other hand, others preferred "not (to) use the word Islamic at all (...). We should take care that we address all people, not just a specific group" (int). Several staff articulated their inner conflict between the two positions. They pointed out how an explicit Islamic portrayal would face resistance both from commercially-minded staff if it limited the bank's market potential and those supporting a more religious purpose as it instrumentalized their religion. One manager articulated his personal struggle:

"It is not non-Islamic, but I have a problem to call it explicitly Islamic, because can we actually satisfy the requirements? ... I do not wish to instrumentalize my religion nor become a victim of my own shortcomings. That's why it is difficult." (int)

The dividing line was not a rift between factions advocating a stronger orientation towards market or religion. Instead, it was an inner, personal conflict over how to communicate one's religion in the context of a bank. To accommodate these diverse views, the bank resorted to visual and verbal presentations that permitted both religious and secular readings. For instance, visual presentations such as images on calendars or products used very subtle religious symbols. Those versed in Islam would recognize their religious connotation, but others could enjoy them as artistic or cultural artifacts (obs). The most visible instance of this interpretive flexibility was KT Bank's logo. It shows a yellow date tree on a green background. For those unfamiliar with the Islamic faith, this may seem an unremarkable choice, possibly evoking a sense of environmental or economic sustainability as supported by mentions of the "long-living and sustainable palm tree" (doc). Muslims, by contrast, would recognize green as the 'color of Islam' and associate the date with divine nourishment: Their prophet Muhammad broke his fasting with dates and the angel told Maryam, mother of Jesus, to "shake toward you the trunk of the palm tree; it will drop upon you ripe, fresh dates" 
(Quran 19:25). The logo is that of KT Bank's holding company, Kuveyt Türk Participation Bank. Managers opted to use the logo, harnessing its potential for multiple interpretations, but they deliberately chose not to use the brand name Kuveyt Türk, abbreviating it instead to "KT" because of concerns about the associations it would evoke in the German market. As a senior manager explained:

"We need to be careful what associations are connected with Kuwait and Turkey. This is why the reorientation to call us KT Bank, not Kuveyt Türk, is a step in the right direction." (int)

KT Bank used the date tree on marketing banners and billboards. These show a date tree transplanted into iconic commercial scenes, such as Frankfurt's financial center or Hamburg's port. They visually convey the union of finance or trade with either sustainability or religion, albeit leaving the exact nature of that relationship to the religious sensitivity of the audience.

The bank's verbal presentation echoed this ambiguity. From among three alternatives, the bank's leadership selected the marketing campaign whose subtle imagery signaled religious values to the religiously informed, while offering secular business readings for everybody else. In fact, a senior manager emphasized their wish to simultaneously speak to different target groups in a meeting with the agency. Central to this subtlety were slogans that play with double meanings in German. For instance, one campaign slogan translates as: "Now there is a bank that does not trade with everything, but always with accountability." Another reads: "Now there is a bank that does not speculate, but invests sensibly." These signaled KT Bank's religious commitments not to speculate or trade in improper goods, but could also be interpreted as a distinctive market position by secular observers. Similarly, the bank's slogan “Islamisch. Sinnvoll. Handeln.” translates as "Islamic. Meaningful. Trading/Acting.” playing on the double meaning of the German word 'Handeln', which means both to act and to trade. To the informed Muslim audience, the latter directly juxtaposes KT bank's activities with charging interest and speculating, echoing the Quranic verse that "Allah has permitted trade and forbidden interest". For others, corporate responsibility, accountability and sustainable 
investment catch the eye, values many non-religious customers would also find appealing, particularly after the financial crisis.

Likewise, KT Bank's vision, mission and press statements used such ambiguity. They frequently referred to deliberately vague higher-order values of sustainability, transparency and trustworthiness, which are not explicitly religious, but straddle market and religious concerns. Indeed, an early working document of the business model included a vision and mission statement that emphasized "no use of religious terms" (doc). The final model only diverged slightly in using no technical Islamic Finance terms and few religious expressions.

Notably, words carrying multiple meanings were not only used in external presentations, but also used internally to embrace different value systems. One manager pointed out that his departmental guidelines explicitly emphasize employees' "responsibility before God and man" (doc). Visibly pleased, he explained that this expression takes pride of place in the preamble to the German constitution, but also communicates his view of Islam:

"This expression strikes at the core of human responsibilities as servant towards the sole sovereign God, namely to do justice to his responsibility - to Allah and his creation, which includes mankind." (int)

Collectively, different means of keeping the bank's emerging purpose vague and communicating it with substantial interpretive flexibility created space for diverging views on what the bank should be and tempered the most severe pressures to retain valued staff.

\section{Polyphony - KT Bank's Staff Taking Space to Practice Their Purpose}

Discussions of what the bank should be invariably refracted into personal conversations about what KT Bank should be for its staff. How would it allow everyone to bring their personal values to work? For some, KT Bank was an exciting new project. For others, it was simply another business. Yet for many, religion was the key motivation to join, which meant a "need to embody our values" (obs). For them, KT Bank was a calling. They sacrificed higher earnings elsewhere for spiritual benefits now and in a Hereafter: "I joined the bank as it is an 
Islamic bank. I am a religious person and I can act accordingly. And I can also help others to act in an Islamic manner" (int).

Embodying personal values was far from straightforward, however. Performance metrics and compliance standards cut across individuals' religious beliefs. Products that over- or underemphasized religious prescriptions or communications were felt to instrumentalize religion in pursuit of profit. As a result, tensions between market and religion not only ran through the bank, but also through most staff as individuals. One interviewee most vividly articulated his personal sense of conflict between mosque and market and the challenge of living one's values in an organization where both overlap:

"We need to avoid this overlapping of multiple personalities. Muslims often play different roles. In the mosque, they are generous and very religious, but at work, they act like capitalists. (...) We need to be consistent and be Muslim in private and in public, in the mosque and at work." (int)

It turned out that management actions to make space for flexible interpretations were only half the story of KT Bank's founding. To our surprise, transgressing even deeply-held beliefs or values was rarely met with open conflict as described above, to the point where we noted it as the exception rather than the rule. While the organization was making space, staff were taking space. That means, they actively created niches to reassert their personal balance between market and religion by moving between different physical places, times or languages. Doing so dampened conflicts between individual colleagues and their competing value commitments, and helped make KT Bank many things to many people. Such individual-level action also escalated back to the organizational level to re-enhance organizational flexibility and maintain the dynamic cohesion of the organization as a whole.

Space. The prayer room was the most intuitive place to note how staff used different physical places to sustain separate conversations and give salience to religion or market. It engaged all senses in carving out space from the office environment. Its spatial separation, incense sticks, devotional atmosphere, and colorful prayer rugs facing Mecca formed a stark contrast to the monotone grey, black and white of the conference facilities, reception areas, 
and work stations. Notably, KT Bank had consciously rented this space in the financial center of Frankfurt, "the finance capital of Germany" (int). From the conference room, which also served as a communal area outside of meeting times, staff looked over the nearby rooftops and straight onto the high-rise headquarters of global banks, the primary buildings in their direct line of sight. Seeing 'eye to eye' with them seemed to inspire some corporate ambition. Sharing a cup of coffee with colleagues, one of them nodded towards the financial center and joked: "In ten years time, maybe we will be there" (obs). While others initially chuckled at his remark, they quickly added that a smaller office in the financial center was not unrealistic.

Different spaces, hence, gave greater or lesser visibility to market and religion, allowing staff to meet like-minded colleagues. Interviewees regularly became very emotional as they described the prayer room as a sanctuary for which they had been yearning. For several of them it was the first time they had a designated space for prayer at work and reported feeling "deeply content" and "grateful" (int) for the fact that KT Bank had made space for their religious practice. This gratitude was particularly explicit around purpose-built ablution facilities. Originally, staff had had to use office restrooms for their ritual washing. Seeing that management responded to this makeshift and undignified practice by literally making space for their faith, reassured many staff.

Five to eight staff participated in daily prayers during the bank's early days, but this number grew up to twenty once the organization reached fifty employees. Yet, there was clearly no pressure to join. Some prayers concluded with a supplication that God may make the bank both religiously observant and financially successful. After prayers, groups frequently stayed to discuss a saying of the prophet Muhammad and its implication for their banking work. For example, a manager cited one saying directly related to competing work demands. "Deeds are (judged) according to intentions", he recited and urged those praying with him to keep their intentions pure at work. Colleagues in the prayer room quietly absorbed his comment, some with serious expressions on their faces, some nodding (obs). Later, one of them explained to 
the first author that he felt anxious at work that his intentions may become impure and punished by God, given the direction of the bank. He confided that conversations with likeminded people, particularly in the prayer room, created a sense of belonging that convinced him to stay for now - even pushing the bank further to a more religious orientation (int).

Therefore, beyond offering a place for collective worship, the prayer room also created a personal opportunity to create a sense of distance from work at work. This, we were told, fostered more candid conversations about being a Muslim in general, and at work in particular. It allowed staff to individually decompress from faith-work conflicts and reassert their personal balance of religion and market. These conversations, respondents told us, recharged them not only spiritually, but also for their work in the office. As a conversation space, the prayer room also facilitated a sense of community and collective response to the challenges of the founding process. It afforded staff space to form convictions and concerns and feed them back for consideration by the wider organization.

Time. Religious practices took place within everyday work routines, albeit at different times. Some staff prioritized worship explicitly over work at specific times, and management formally granted them the flexibility to do so (doc). Religious practices typically took staff away from their desks, a situation that employers usually seek to minimize. Yet, management typically scheduled meetings around prayers or paused for them (obs). On Fridays many employees extended their lunch break, self-selecting into groups of like-minded colleagues when visiting the mosque together for the congregational midday sermon and prayer (obs), as the Quran restricts work at this time:

"O you who have believed, when the prayer is called for on Friday, then proceed to the remembrance of Allah and leave trade (...)." Quran (62:9)

The role of time was particularly visible during the fasting month of Ramadan. Every day a group of people congregated for one hour around lunchtime to pray and read a 20-page section of the Quran, making substantive time for their religious observances during their 
working day. Meanwhile, staff who did not fast returned to their desks after a brief lunch break. In addition, staff that fasted used the bank's flexible working hours to start work late in the day and continue late into the evening. This meant that they could resume work after breaking the fast at sunset, attend ceremonial and religious practices at night, and reduce daytime working hours while fasting. On average, employees who did not fast started work earlier than those who fasted, which affected the composition of staff in the office in the mornings and evenings. After breaking their fast one evening, we observed that some employees stayed at the bank until their fast for the next day. They prayed together and sat in the office until dawn discussing, inter alia, the future of the bank. In this discussion managers conveyed their desire for a more religious bank and others nodded and expressed support. Some offered specific suggestions like having a weekly session with external Islamic Finance experts on how to market the bank or what products to develop (obs). As a result, some of them started organizing weekly sessions and external speakers; however, senior management shelved this because it was deemed too time intensive during the founding process and the group agreed to revisit this initiative at a later stage.

Languages. Finally, staff accommodated competing commitments to religion or market through languages. Intuitively, people spoke 'banking' predominantly through the language of numbers, but also couched their concerns in professional jargon and abbreviations. They used complicated financial models and spreadsheets which only experts could decipher or referred to their minimum requirement for risk management as "MaRisk" (obs.). The first author noted that they could have a separate conversation even while in the same room at the same time as their non-expert peers. The 'outsider' co-authors noted the same mechanism for carving out a niche for religious sentiments. People expressed them in Turkish or Arabic, rather than in the official office languages, English or German. They fluidly switched languages in both informal conversations and formal meetings. For instance, Muslim employees used religious greetings such as "Selamun aleykum" ("peace be upon 
you'), or closed with religious phrases like "inshaAllah" ('God willing'). Even though some non-Muslims appropriated these phrases to build rapport, their religious peers indicated that they appreciated the gesture while acknowledging that it had no genuine religious intent.

This fluid switching was not limited to greetings and phrases, though. Even in formal business meetings, staff switched languages. Despite agreeing on German and English as office languages, senior managers explained to us that this policy was not codified or enforced. This flexibility avoided conflict and offered the benefit that those who were less fluent in English or German could switch to their mother tongue when necessary to improve speed and accuracy of communication with other native speakers. However, many used such language switches to offer side remarks to those few speaking the same language. Hence, even when in the same room at the same time, employees could use language to selectively communicate personal and religious views that they did not wish to share with the plenary. They could thus avoid publicly pitting their religious views against business reasoning and exposing themselves to the likely push-back. For instance, while discussing a profit sharing ratio between the bank and its customers, one employee queried another: "Aslında böyle yapmamamız lazım, değil mi?" - “Actually, we should not do it this way, right?" His counterpart nodded, agreeing that a very small profit share for customers was potentially not Islamic compliant, before turning back to the speaker.

Employees regularly invited others in the office to join them for communal prayer. We recurrently observed how this happened in Turkish, in effect excluding non-Muslim German speaking employees. Yet, both sides appeared comfortable with this arrangement, because Turkish speaking Muslims did not have to directly address non-Muslims, who equally did not have to decline the invite. Ironically, then, a practice that initially seemed discriminating to the observer was used to divert attention away from religious differences and avoid conflict.

To summarize, to our surprise KT Bank staff not only found ways to have different 
conversations in different places and at different times. They also used different languages, within the same place and at the same time as a means of having multiple concurrent, yet separate discussions, each foregrounding a different set of concerns, i.e., market and religion.

\section{Elastic Hybridity - Making it to the Starting Line}

Despite indisputable and persistent tensions between banking objectives and religious considerations at every level of the organization, KT Bank managed to embrace both. The bank offered space and flexibility for staff to fluidly and dynamically accommodate their competing commitments and dampen personal conflicts. The deliberately vague positioning of the bank, its ambiguous visual and verbal presentations, and the ability for staff to find their own niches through the conscious use of place, time and languages, jointly created an inclusive, open and resilient organization, able to embrace a diversity of views on the balance of banking and religion.

Inclusiveness. When we asked employees where they thought the bank was and ought to be on a market-to-religion continuum, we found little agreement on its perceived or aspired balance. Rather, after an initial period of prescription, open conflict, and (threatened) departures, the bank became many things to many people. Our interviews revealed how, right up to the point of its founding, divergent views persisted on the role of religion vis-a-vis banking. As one manager remarked: "The business model is driven by religion", only to quickly add "dependent on how one interprets religion" (int). Similarly, another manager compared his own religious views to some of his peers:

"Some might say that an Islamic bank means offering formally Islamically structured products. (...) However, personally, I think an Islamic bank is, rather, a bank which implements the intentions of the Sharia or Islam and which has its focus there." (int)

Crucially, the bank embraced these diverse convictions and used them as feedback to frame inclusiveness. This was important, as one interviewee noted, because:

"When you say 'Muslim', there is no prototypical Muslim. There are many different types of Muslims. And there will be different types at our bank, too." (int) 
KT Bank chose to allow employees to express and enact their own balance of religion or market because, as one manager highlighted: "The Quran says that there is no compulsion in religion. And so there is no compulsion of religion with us" (int).

Optionality. The corollary of being inclusive to different "types" was to grant different options to practice faith. Indeed, throughout the founding process, the leadership team became more open to different options, rather than more restrictive. They absorbed, recovered and learned from initial conflict over central concerns such as finding its organizational purpose or policies on personal appearance. Ultimately, staff were given choice over their appearance echoing the vagueness and flexibility of the banks' purpose in its employees' internal practices. Having learned the lesson that the more prescriptive the practice, the more open and fierce the conflict, the leadership team changed their approach, as evidenced in the organization of the opening gala. The team carefully crafted a common visual identity for the event, to the extent of having staff attire mirror the highly symbolic color scheme of the bank's logo. Female employees were given the option whether to wear their scarf as a headscarf or a shawl. Similarly, management emphasized the choice of using prayer facilities or not, one manager tellingly couching the explanation for this policy in a religious pun when saying: "I think, everyone here can find their own way to sainthood. That is what makes the whole thing so exciting" (int). Such options were accommodating to divergent views and practices. Yet, flexibility did not mean a free-for-all. Flexibility, and the diversity it begot, became a cherished feature of the organization and a key step in getting to the starting line:

\footnotetext{
"Some colleagues are Muslims and wish to fulfill an act of worship building this bank. Others are here because they find this an interesting venture, building a bank - and even an Islamic one. Some are here because they believe in ethical banking and think KT Bank is a step in the right direction. And of course, some are here because they got a good offer: more money, a better position. We are all working on the same project and although we have different motives, maybe even different goals, we move this project forward together." (int)
}

\section{DISCUSSION}

Drawing on a 24-month ethnography of the first Islamic bank in Germany, we explain how hybrid organizations can reduce conflict and leverage synergy between coexisting logics 
when organizational, structural and static solutions such as compartmentalizing or blending are not feasible. In this section, we develop three contributions that jointly explain how contested hybrids may engage incompatible logics to accomplish what paradox scholars call a "unity of opposites" (Schad et al., 2016: 36). First, based on the ways KT Bank and its staff make and take space for central, incompatible logics, we theorize the mechanisms of polysemy and polyphony. Polysemy sustains organizational integrity. It accommodates diverse personal convictions and reduces conflict between the organization and its staff. Meanwhile, polyphony sustains individual integrity. It reduces conflict among staff as they take space to each enact their respective convictions as enabled by the organization. The recursive interplay of polysemy and polyphony across organizational and individual levels dynamically reduces intra-organizational and inter-subjective conflict. We therefore conceptually integrate polysemy and polyphony to explain how both jointly constitute elastic hybridity. Lastly, we explain how elastic hybridity makes contested hybrids sustainable. We argue that the interplay of polysemy and polyphony dynamizes Besharov and Smith's (2014) framework. They flexibly and temporarily render coexisting logics either more compatible (polysemy) or less central (polyphony), allowing elastic hybrids to keep competing logics at their core, avoid extensive conflict, and successfully become many things to many people. This facilitates a paradoxical sense of unity in diversity, which, in turn, makes contested hybrids more resilient against fragmentation, paralysis, and demise. By explaining how organizations can empower staff to practice more of their ideals at work, we also advance the agenda of creating more purposeful organizations.

\section{Dynamically Engaging Competing Demands Through Polysemy and Polyphony}

Polysemy. We theorize KT Bank's deliberate lack of clarity about its purpose, positioning, and presentation as polysemy. Polysemy is the judicious use of concepts, words, artifacts or images that support multiple meanings, or logics, and so help reduce conflict between their representatives. We consider it an organizational response to institutional 
complexity as it creates conditions for individuals to manage their own competing institutional commitments. Drawing on Zilber's (2011: 1543) notion that polysemous words or symbols have an "ability to be interpreted in different ways in different contexts" we use its resonance with the paradoxical "unity of opposites" (Schad et al., 2016: 36) to apply polysemy to the accommodation of incompatible logics.

Polysemy complements existing approaches to institutional complexity. In contrast to blending, it does not assume a minimum compatibility of logics or flexibility of staff to synthesize an organizational purpose (Battilana \& Dorado, 2010; Binder, 2007). Instead, polysemy supports the coexistence of multiple purposes or meanings. It construes and communicates vagueness about institutional demands and so offers external and internal constituents space for their own diverse, even conflicting interpretations to coexist in the same context. This "unified diversity" (Eisenberg, 1984: 230) sustains the hybrid, even in times of contestation.

Polysemy also offers more flexibility for individuals to practice their values and dynamically balance their institutional commitments where established structural approaches would leave them little room to do so. The organization does not prescribe any desired equilibrium (Smith \& Lewis, 2011) or structurally cement a balance of logics in the elements it selectively couples (Pache \& Santos, 2013). Instead, through polysemy, it opens up interpretive spaces in which frontline staff - and not just senior managers (Smith \& Besharov, 2018) - can personally and dynamically balance competing demands for themselves. The concept of polysemy thus extends both institutional and paradox theory. It is more sensitive to the individual-level dynamics of frontline staff balancing competing logics (Smets et al., 2015) and to the paradox of "belonging" when individuals carry competing identities (Smith \& Lewis, 2011), both of which have received little attention to date (Schad et al., 2016). In our case, polysemy takes two forms, which we call conceptual and presentational. 
Conceptual polysemy manifested itself in KT Bank's reluctance to develop a clear business position and precise answers to central questions such as: What is Islamic banking? What is Sharia-compliant? While the questions gave prominence to religion within KT Bank, the absence of clear answers made space for diverse beliefs and enactments of this logic. As the vaguely worded articles of association and inclusive expressions by senior managers showed, openness was a conscious choice, reminiscent of Selznick's (1957) argument that organizations with more abstract mission statements can both institutionalize and adapt. The conceptual vagueness created space for employees' individual judgments of the organization's purpose and its legitimacy as an employer. As evidenced by the few staff departures we saw and the 'lost faith' when the bank did try to impose a specific religious practice or balance between religion and market, this polysemic behavior was critical for retaining and uniting staff who were scarce and influential, yet diverse. In contrast to Reay and Hinings' (2009) case in which representatives of conflicting logics bonded over working against a common 'enemy', such a catalyzing third-party was absent from our case. Instead, the key concern was for the nascent organization to get to the 'starting line' (Almandoz, 2012). There was no effective catalyst; or, as one respondent put it, no way to "enforce" religion in a particular way. Our findings therefore suggest more broadly that where organizations deal with beliefs which individuals consider their "ultimate concern" (Tillich, 1957: 8), they have no means of prescribing a 'correct' belief or balance of competing concerns. Their only way to engage competing beliefs is to make space for them.

Presentational polysemy is a close complement to conceptual polysemy, as it captures the textual and visual manifestations by which conceptual spaces are kept open. It maintains a sense of ambiguity, which "allows for different courses of action while maintaining a semblance of unity" (Giroux, 2006: 1232, emphasis in original). Only a few institutional theorists have considered ambiguity and vagueness - and only at the field level (e.g., Cornelissen et al., 2015; Meyer \& Höllerer, 2016). Under these conditions, "the degree of 
incompatibility between logics is tempered and, importantly, the discretionary ability of organizations to reconcile competing logics — whether substantively or symbolically—is significantly enhanced" (Greenwood et al., 2011: 333). Thus, while the enabling properties of field-level ambiguity have been recognized, their potential for the active management of institutional complexity has remained unexplored. It is specifically organizational actors' ability to "both construct ambiguous meanings and exploit the ambiguity within organizations as a possible resource for strategic action" (Sillince, Jarzabkowski, \& Shaw, 2012: 632) that strategy scholars highlight and we draw upon in our construction of polysemy as a mechanism for reducing conflict in contested hybrids.

Taking these insights from strategy into the institutional realm, presentational polysemy highlights the viability of competing interpretations and actions under a single organizational umbrella. It lends credence to the argument that communication constitutes institutions (Cornelissen et al., 2015) taking seriously that "any performance is as much the product of the agent that/who is deemed performing it as the product of the people who attend and interpret/respond to such performance" (Cooren, Kuhn, Cornelissen, \& Clark, 2011: 1152). Presentational polysemy thus challenges the assumption of more deterministic institutional accounts that institutional or managerial influences are received like edicts. Instead, it takes into account "the interpretative propensities and capabilities of the alleged receiver" (Christensen \& Cornelissen, 2011: 391) supporting multi-level, recursive understandings of how organizations and their members collaborate in their management of institutional complexity. Their discourse is not to be conceptualized "as a window to feelings and cognitions, but as a key to how paradox forms and operates" (Putnam, Fairhurst, \& Banghart, 2016: 77). Presentational means, such as logos, mission statements or advertising slogans are not mere conduits for discourses, but constitutive of social and institutional reality (Ocasio, Loewenstein, \& Nigam, 2015). Polysemy fosters thus a sense of collectivity and social identity - despite diversity. 
In our case, KT Bank carefully crafted polysemous expressions, artifacts and images. Most visibly, it used the "plurality and openness of meaning" (Cornelissen, 2005: 753) of the date tree in its logo. It sent a strong religious message to those familiar with Islamic symbolism, but signaled environmentalism and sustainability to others. This effect was reinforced as the symbol pointed to a story, not a concrete concept. Doing so harnessed the power of storytelling to build legitimacy for a new venture (Lounsbury \& Glynn, 2001), but simultaneously expanded the scope for action because, "the more ambiguous the message, the greater the room for projection" (Eisenberg, 1984: 236).

These findings supplement Peifer's (2014) insight that strictly faith-based funds combine unequivocal religious iconography with market symbolism. Intuitively, then, it makes sense to opt for more ambiguous symbolism where religion itself is a contested part of the organization. In such contested contexts, Giroux (2006: 1229) suggests, organizations should issue "normative texts (e.g. missions, goals or plans) that can be espoused by everyone while at the same time allowing for different interpretations". Doing so reduces organizational conflict over individual strategic interests and reduces the risk of fragmentation (Heracleous \& Barrett, 2001). We concur, but argue that potential for conflict is much more pronounced where it is over deep-seated personal values and beliefs, not personal goals. Its management is even more problematic where competing beliefs are held by individual people, rather than by different audiences. It is in these situations that decoupling (Meyer \& Rowan, 1977) fails, because managers cannot say different things to different people. If they did, recipients would be particularly unforgiving about the organizational hypocrisy (Brunsson, 1989). That is why polysemy is so critical for the management of contested hybrids: It creates flexibility without hypocrisy. Managers say the same thing to different people, who then hear it differently.

Polyphony. Polyphony is an indispensable counterpart to polysemy. It describes how individuals use the interpretive spaces, which the organization opened - and kept open through conceptual and presentational polysemy. Polyphony, literally means 'many voices' 
and describes the coexistence of a "multiplicity of independent and unmerged voices and consciousnesses" (Bakhtin, 1984: 208). Polyphony, the mechanism behind this multivoicedness, is an individual's judicious use of place, time, and/or languages to enable simultaneous, but separate enactments of competing logics.

This ability is so critical because polysemy is used primarily when organizations cannot separate specific audiences to tailor their message (Meyer \& Höllerer, 2016). Separation, however, is key for individual staff. It builds identification through interaction with peers (Besharov, 2014), and protects from scrutiny by those with competing commitments (Smets et al., 2015). While polysemy helps the organization avoid conflict between its mission and staff by making space for their diverse beliefs, it creates potential for conflict among staff. Mechanisms for 'making space' therefore need to be complemented by mechanisms for 'taking space'. They allow staff to practice their various beliefs without scrutiny or disapproval from others, and to shape organizational structures through their practice. Polyphony is such a mechanism permitting individuals in the same organization to practice different self-selected prescriptions.

Polyphony transcends what has previously been reported in the literature in three ways: First, it broadens the nascent literature on the role of physical places in institutional dynamics (Furnari, 2014; Kellogg, 2009) and adds the dimension of language to existing notions of spatial and temporal differentiation. Second, it personalizes the separation and integration of competing logics. Specifically, polyphony complements recent work (Smets et al., 2015; Smith \& Besharov, 2018) by showing that not only do organizational structures enable individuals' dynamic balancing of competing logics, but also highlighting how individual balancing feeds back to the organizational level. It is not managerial "guardrails" (Smith \& Besharov, 2018) that delineate how broad the space for experimentation needs to be, but the frontline staff and their polyphonous practices. In short, polyphonous practices delineate the necessary breadth or boundaries of polysemy. Third, it explains how the "constant motion 
across opposing forces" characteristic of the "organizing" paradox of separation and integration (Smith \& Lewis, 2011: 386), is accomplished by individuals literally moving across places, times and languages.

Spatial polyphony exists when institutional logics coexist in an organization, albeit in different places. Spatial separation resonates with established concepts of structural hybridity and compartmentalization in the institutional literature (Kraatz \& Block, 2008; Reay \& Hinings, 2009), or spatial "splitting" in the paradox and ambidexterity literature (Poole \& Van de Ven, 1989; Smith \& Tushman, 2005). Yet, spatial polyphony differs in one critical aspect: It is not a rigid organizational solution to hybridity that structurally dictates the centrality of a belief, value or logic, but a personal one. It grants staff discretion to inhabit different physical places as they choose - not as the organization prescribes. In this sense, spatial polyphony resonates with recent work on "relational spaces" (Kellogg, 2009) and "segmenting" (Smets et al., 2015) which emphasize the exclusion of those representing a competing logic and the freedom from interference for the 'insiders'. In Smets et al.'s (2015) study of Lloyd's of London, reinsurance underwriters are 'safe' from community peer pressure in the office, enabling them to give more presence to the market demands of their management and to balance their commitment to the competing logics of community and market. In Kellogg's (2009) study, hospital change agents use their relational space to discuss their initiative free from interference by change resistors.

However, spatial polyphony is different from these established concepts which allows us to extend existing theory. In comparison to Kellogg's (2009) and Smets et al.'s (2015) concepts, spatial polyphony is both more personally and organizationally embedded. It is more personal insofar as the use of different places is entirely in the discretion of individuals and there is no organizational expectation or workflow pressure to occupy specific places at specific times such as, for instance, in the case of trading hours in Lloyd's of London. Individuals therefore have greater personal discretion to take different organizational spaces that represent different 
logics as they see fit to find "breathing space" for their personal values and beliefs (Kreiner, Hollensbe, Sheep, Smith, \& Kataria, 2015: 1004). Polyphony is also more organizationally embedded in that individuals do not simply take a vacant or neutral place and make it their own, as Kellogg's (2009) change agents did. Instead, they choose to move into a purposebuilt space whose material design and symbolic purpose give presence and prevalence to a particular logic. Arguably, in providing such a space, an organization signals its commitment to the logic being represented, acknowledges its centrality and allows for spillover effects into the entire organization. This stands in marked contrast to Kellogg's (2009) example in which change agents use their relational space to assert their suppressed logic and to escape from the clearly dominant alternative in their organization. In our study, spaces were means for stability rather than change. Participants positively noted the fact that KT Bank offered purpose-built prayer and ablution facilities which, to them, signaled that both banking and religious logic were seen as equally deserving of dedicated facilities.

Temporal polyphony describes the "temporal separation" (Poole \& Van de Ven, 1989: 566) of institutional logics within an organization, which may result in one logic being temporarily more central at one time, and its alternative at another. In contrast to spatial polyphony, different 'voices' may occupy the same physical space - albeit at different times - as evidenced, for example, by the restructuring of working hours during Ramadan. Temporal polyphony, hence, resonates with the notion of "temporal structuring" insofar as staff use "temporal structures to guide, orient, and coordinate their ongoing activities" (Orlikowski \& Yates, 2002: 684). However, temporal polyphony is not limited to coordinating activities, but extends to their underpinning institutional logics. In fact, activities and their temporal structuring coordinate competing logics, not the other way around.

With few exceptions (Raaijmakers et al., 2015; Reinecke \& Ansari, 2015), temporality as a mechanism for managing institutional complexity has received limited attention. In this sense, temporal polyphony constitutes a new and important complement to its spatial variant. It 
helps organizations to dampen conflicts among staff inhabiting the same space. Notably, it is not the organization prescribing the performance of different activities at different times, but individuals using temporal structures of their work to decompress tensions between central, incompatible logics, making one of them more or less present and central at specific times.

Multilingual polyphony exists where representatives of competing logics are physically copresent, but separated by languages. While spatial and temporal polyphony are intuitive insofar as "social paradoxes are about a real world subject to its temporal and spatial constraints" (Poole \& Van de Ven, 1989: 565), multilingual polyphony adds a third dimension. It affords "the mental compression or expansion of space and time" to surface or recede tensions (Schad et al., 2016: 24). In our case, business was typically conducted in English or German, but religious matters were commonly raised in Turkish or Arabic to ensure that like-minded individuals were included in the conversation, but others were not. As with spatial and temporal polyphony, this mechanism allows multiple logics to coexist so that scrutiny by representatives of competing logics is minimized and the potential for conflict reduced.

The role of discourse has long been analyzed in institutional theory (Phillips, Lawrence, \& Hardy, 2004; Suddaby \& Greenwood, 2005). Yet, scholarly focus has firmly remained on the rhetorically skilled use of language rather than languages. By contrast, multilingual polyphony foregrounds the ability of polyglots to choose which language to communicate in so as to include or exclude selected peers. It creates environments in which views can safely be voiced, especially where logics and languages broadly align. This dynamic is not limited to logics of religion and market or the temporary segmentation of logics. Smets et al. (2012) in their study of a global law firm, for instance, found that when English and German lawyers responded to queries in each other's language, they created a potent vehicle for reconciling their contradictory professional logics and consolidating their emergent hybrid practice. In her research at high-tech conferences in Israel, Zilber (2011) highlights the connotation of 
speakers choosing Hebrew or English, to connect with either the national or the global community. As simultaneous translations existed, language choice was not a mechanism of exclusion but identification and signaling. Multilingual polyphony, hence, appears of broader relevance to multinational companies and field-level events, which have previously been examined through the lens of discourse or rhetoric, but not languages.

\section{Elastic Hybridity}

Polysemy and polyphony - through their recursive interplay across organizational and individual levels - jointly help hybrids dynamically engage central and incompatible logics. As KT Bank was unable to impose a single balance of logics on its staff it had to be more inclusive and present multiple options to afford each employee the flexibility to strike a personal balance; even at the risk that this might clash with the balances other staff had struck. In fluidly moving across spatial, temporal and linguistic spaces individuals give different salience to alternative logics and dynamically balance them as well as any tensions with the balances of others. We interpret this dynamic state of tension as one of elastic hybridity. It is constituted through the recursiveness of polysemy and polyphony and combines organizational unity with individual diversity.

We illustrate these dynamics in Figure 3. Borrowing paradox scholars' 'yin and yang' imagery the two central, incompatible logics A and B jointly constitute the organization. On the left, both are separated by one solid vertical curve to represent static, structural hybrids with a fixed balance of logics. By contrast, on the right, multiple dashed curves illustrate how balances of logics may coexist and dynamically fluctuate to create elasticity. Elastic hybrids do not seek the "neutralization" of competing institutional demands (Meyer \& Höllerer, 2016: 3) so that they become neither one nor the other. Instead, they celebrate their constructive 'both/and' embrace. They do so by decompressing them as individuals temporarily inhabit different spaces and come back together, finding what others have described as "wiggle room" or "breathing space" for their convictions (Kreiner et al., 2015: 1004). As staff find 
room to re-balance logics at a personal level, the organization becomes effectively a range of hybridities simultaneously, instead of consecutively over time (Smith \& Besharov, 2018), and effectively "multiple things to multiple people" (Kraatz \& Block, 2008: 244).

Insert Figure 3 about here

This personalized and dynamic form of hybridity stands in stark contrast to established alternatives in the institutional literature that structurally decrease centrality or incompatibility of logics by separating or combining them. In compartmentalized or selectively coupled hybrids, organizational structures permanently cement an organizationally prescribed balance of two logics, as illustrated in the static hybrid case in Figure 3. This solution becomes problematic when institutional fissures not only run through the organization, but also through its people, and balances of logics need to shift dynamically. An organizationally imposed centrality, and dominance, of one logic vis-à-vis another in certain parts of an organization then clashes with diverse individual beliefs and hampers integration as we exposed earlier.

Likewise, elastic hybridity offers an alternative to blended hybrids, as it still functions when theoretical conditions for blending are not given. Where organizations cannot engineer a strong common identity through recruitment and socialization, count on the cognitive and normative flexibility of their staff or leverage a basic compatibility of logics, elastic hybridity offers an alternative way to "gain acceptance among members for broadening organizational goals" (Kreiner et al., 2015: 1006). This means that elastic hybridity is especially critical in the case of greedy, incompatible logics, whose demands manifest in strong convictions that are not malleable or open to compromise and de facto beyond organizational authority. In this sense, elastic hybridity prevents the breakdowns which "institutional plasticity" (Lok \& de Rond, 2013: 205) helps to repair. 
Echoing Smets et al.'s (2015) notion of "segmenting", paradox scholars' notion of “engagement" (Schad et al., 2016) as well as Smith and Besharov's (2018) "paradoxical frames", elastic hybridity facilitates more fluid transitions between separation and integration, as individuals flexibly engage competing logics. It explains how hybrids can balance competing demands when permanently decreasing their centrality through structural compartmentalizing and structurally decreasing their incompatibility through blending are both infeasible. It helps engage the paradoxical tension for organizations to keep contested practices "below the radar of opponents and skeptics" (Briscoe \& Murphy, 2012: 577), while simultaneously being visible to supporters, and integrated across time and space. Doing so also contributes to the recent paradox literature and its quest to understand how organizations sustain dynamic equilibria (Schad et al., 2016). In contrast to prevailing accounts in both the institutional and the paradox literature, elastic hybridity democratizes the management of institutional complexity, insofar as it no longer portrays balancing as the prerogative of managers (Smith \& Besharov, 2018), autonomous professionals (Smets et al., 2015) or senior executives (Smith, 2014), but as the interplay between organizational structures and staff actions across the entire organization. We thus expand the notions of "paradoxical frames" and "structured flexibility" (Smith \& Besharov, 2018) through a multi-level model.

Battilana and colleagues (2015: 1679) suggest that one condition to "resolve" or "overcome" paradox in a hybrid may be the partial unfreezing of its imprint. An elastic hybrid accomplishes exactly that, and more: It dynamically freezes and unfreezes the impact of underlying logics on the organization and its staff. Yet, dynamism allows elastic hybrids to engage both logics and embrace them dynamically rather than to permanently resolve paradox. They dynamically separate and integrate enactments of competing logic, which are both equally central to the task at hand without a wholesale structural or cultural restructuring of the organization. This solution harnesses paradox scholars' insight that tensions are never resolved or overcome but, at best, dynamically balanced. It is thus critical when fragmentation 
is a real risk, change is not an option and the organizational goal is the maintenance of a paradoxical status quo (Jay, 2013). An elastic hybrid continuously and dynamically handles the persistence of institutional tensions to decrease conflict and to deal in particular with performing paradoxes that embrace varied goals (Smith \& Lewis, 2011).

\section{Rendering Contested Hybrids Resilient through Elastic Hybridity}

The concept of elastic hybridity and its constitutive mechanisms of polysemy and polyphony dynamize Besharov and Smith's (2014) framework and explain how to manage the most contested instances of hybridity. Simply put, elastic hybridity allows organizations to retain competing logics as both central and incompatible, but temporarily decrease their centrality and incompatibility to reduce conflict. Rather than permanently move to a more aligned or estranged state, an elastic hybrid makes its contested nature more manageable. We visualize this in the grey semi-circles in Figure 4, which move out and expand the boundaries of the contested quadrant. Polysemy makes competing logics appear more compatible through the ambiguity and interpretive flexibility it offers. Simultaneously, polyphony allows individuals to better cope with potential tensions by making one of two logics less central in a particular place, time and/or language. Elastic hybridity thus affords hybrids the resilience to institutionally bend but not organizationally break as they accommodate shifting or uneven salience of competing logics. For the hybrid organization, logics remain central and incompatible, yet contest is reduced.

Insert Figure 4 about here

Importantly, then, while one logic may be more central in one place, time or language, and the alternative logic more central in another, individuals' ability to fluently move between those places, times and languages allows them to dynamically balance their relative centrality to the organization. However, as individuals temporarily reduce one logic's centrality, but 
subsequently return to re-engaging both logics, the organization as a whole would not permanently shift into an estranged position.

Institutional tensions and resulting paradoxes are not resolved but rather dynamically embraced as individuals' positions fluctuate. Elastic hybridity hence not only helps nascent ventures to get to the start line, but also to retain their flexibility and resilience during later stages of their existence. Therefore, potentially contested organizations which support elastic hybridity and enable individual staff to relatively effortlessly manage their personal balance of competing logics may not get caught in a situation of intractable conflict as Besharov and Smith (2014) suggest. Instead, elastic hybrids enjoy greater robustness and resilience.

\section{CONCLUSION}

Our study of the first Islamic bank in Germany revealed how a nascent hybrid organization can manage tensions between logics that are both central and incompatible. Despite representing what Besharov and Smith (2014) consider the most conflict-prone of logics constellation, the bank mitigated against conflict and successfully made it to the starting line. How it did so offers important insights for scholars of organizational hybridity (Battilana \& Lee, 2014; Greenwood et al., 2011) and their nascent dialogue with paradox theory (Smets et al., 2015; Smith \& Besharov, 2018; Smith \& Tracey, 2016).

Casting these different theoretical lenses on our case, we developed two mutually reinforcing mechanisms, which we labeled polysemy (conceptual and presentational) and polyphony (spatial, temporal and multilingual). Through their interplay, the organization and its members jointly co-produced a state of elastic hybridity. This allowed the organization to dynamically engage competing logics and their paradoxical demands, because it did not rely on their structural and static separation or combination. The elasticity dynamizes Besharov and Smith's (2014) framework and explains how contested hybrids can be made to last. It offers organizations the means to dynamically reduce conflict without having to marginalize 
one logic as less central, nor having to cast coexisting logics as compatible per se. Rather than attempting to resolve competing institutional demands, organizations engage them constructively and become more resilient in the process.

These insights are empirically relevant not only because Islamic banking constitutes a fast growing segment of the global finance sector. Islamic banks in the Western contexts are particularly instructive because some consider Islamic banking as a potential corrective to the conventional banking practices that lead to the global crisis in 2008. Our findings also have broader significance, insofar as hybrid organizations from healthcare to professional firms to social enterprises fulfill significant societal roles. Our theoretical contributions help understand how they can be more resilient in even the most contested of circumstances and become more adaptable to volatile institutional demands. Concretely, our insights allow elastic hybrids to re-balance logics without having to structurally re-organize the organization or re-engineer its culture, arguably making such shifts more practical for organizations. This dynamism is also important for the individuals inhabiting hybrids, as elasticity empowers their members to practice more of their ideals at work and still experience a compelling sense of shared organizational purpose. At a time when polarization, fragmentation and volatility increasingly characterize societies, it appears a worthwhile cause to explain how organizations can foster such a sense of unity in diversity.

We note three boundary conditions, which make our qualitative case a highly instructive one. First, we focused on a nascent organization, seeking to make it 'to the starting line'. This situation exacerbates risks of fragmentation and paralysis and highlights the need for inclusiveness as staff departures are hard to compensate. Second, the organization was located within a specific socio-cultural context that combined the market logic with a religious logic from a different or 'foreign' interinstitutional system, which is a particularly conflict-prone setting (Gümüsay, 2017). We maintain that our implications are very likely to be applicable in more established settings as well as in cases with logics from the same interinstitutional 
system that are potentially less conflictual. Third, religion represents a 'greedy logic' that is particularly difficult to accommodate or compromise and is at the heart of many of the defining tensions and grand challenges of our time (Grim, 2016). That said, this does not make religion unique, but particularly revelatory, especially with a view to other 'normative logics' such as community, family and profession, under which we expect dynamics similar to the ones identified here to hold, albeit possibly in weaker forms. Given violent conflicts and wars that are still fought in the name of and against religions, as well as political and social struggles about the role of religions in societies around the world, forming inclusive organizations that encompass religious variety and freedom, and more generally a plurality of values and beliefs, is both a grand challenge and opportunity of our time. It is also a worthwhile and exciting pursuit for further research. 


\section{REFERENCES}

Almandoz, J. 2012. Arriving at the starting line: The impact of community and financial logics on new banking ventures. Academy of Management Journal, 55(6): 13811406.

Almandoz, J. 2014. Founding teams as carriers of competing logics: When institutional forces predict banks' risk exposure. Administrative Science Quarterly, 59(3): 442-473.

Andriopoulos, C., \& Lewis, M. W. 2009. Exploitation-Exploration Tensions and Organizational Ambidexterity: Managing Paradoxes of Innovation. Organization Science, 20(4): 696-717.

Ayub, M. 2007. Understanding Islamic finance. Chichester, West Sussex: Wiley.

Bakhtin, M. M. 1984. Problems of Dostoevsky's poetics. Minneapolis: University of Minnesota Press.

Battilana, J., \& Dorado, S. 2010. Building sustainable hybrid organizations: The case of commercial microfinance organizations. Academy of Management Journal, 53(6): $1419-1440$.

Battilana, J., \& Lee, M. 2014. Advancing research on hybrid organizing - Insights from the study of social enterprises. The Academy of Management Annals, 8(1): 397-441.

Battilana, J., Sengul, M., Pache, A.-C., \& Model, J. 2015. Harnessing Productive Tensions in Hybrid Organizations: The Case of Work Integration Social Enterprises. Academy of Management Journal, 58(6): 1658-1685.

Besharov, M. L. 2014. The Relational Ecology of Identification: How Organizational Identification Emerges When Individuals Hold Divergent Values. Academy of Management Journal, 57(5): 1485-1512.

Besharov, M. L., \& Smith, W. K. 2014. Multiple institutional logics in organizations: Explaining their varied nature and implications. Academy of Management Review, 39(3): 364-381.

Binder, A. 2007. For love and money: Organizations' creative responses to multiple environmental logics. Theory and Society, 36(6): 547-571.

Boone, C., \& Özcan, S. 2016. Ideological Purity vs. Hybridization Trade-Off: When Do Islamic Banks Hire Managers from Conventional Banking? Organization Science, 27(6): 1380-1396.

Briscoe, F., \& Murphy, C. 2012. Sleight of Hand? Practice Opacity, Third-party Responses, and the Interorganizational Diffusion of Controversial Practices. Administrative Science Quarterly, 57(4): 553-584.

Brunsson, N. 1989. The Organization of Hypocrisy: Talk, decisions and actions in organizations. John Wiley \& Sons.

Chan-Serafin, S., Brief, A. P., \& George, J. M. 2013. Perspective-How Does Religion Matter and Why? Religion and the Organizational Sciences. Organization Science, 24(5): 1585-1600.

Chia, R., \& Najak, A. 2017. Circumventing the Logic and Limits of Representation: Otherness in East-West Approaches to Paradox. In W. K. Smith, M. W. Lewis, P. 
Jarzabkowski, \& A. Langley (Eds.), The Oxford handbook of organizational paradox: 125-140. Oxford: Oxford University Press.

Christensen, L. T., \& Cornelissen, J. 2011. Bridging Corporate and Organizational Communication: Review, Development and a Look to the Future. Management Communication Quarterly, 25(3): 383-414.

Cooren, F., Kuhn, T., Cornelissen, J. P., \& Clark, T. 2011. Communication, Organizing and Organization: An Overview and Introduction to the Special Issue. Organization Studies, 32(9): 1149-1170.

Corley, K. G., \& Gioia, D. A. 2004. Identity Ambiguity and Change in the Wake of a Corporate Spin-Off. Administrative Science Quarterly, 49(2): 173-208.

Cornelissen, J. P. 2005. Beyond Compare: Metaphor In Organization Theory. Academy of Management Review, 30(4): 751-764.

Cornelissen, J. P., Durand, R., Fiss, P. C., Lammers, J. C., \& Vaara, E. 2015. Putting communication front and center in institutional theory and analysis. Academy of Management Review, 40(1): 10-27.

Creed, W. E. D., DeJordy, R., \& Lok, J. 2010. Being the change: Resolving institutional contradiction through identity work. Academy of Management Journal, 53(6): 13361364 .

Dalpiaz, E., Rindova, V., \& Ravasi, D. 2016. Combining Logics to Transform Organizational Agency: Blending Industry and Art at Alessi. Administrative Science Quarterly, 61(3): 347-392.

D'Aunno, T., Sutton, R. I., \& Price, R. H. 1991. Isomorphism and External Support in Conflicting Institutional Environments: A Study Of Drug Abuse Treatment Units. Academy of Management Journal, 34(3): 636-661.

DeJordy, R., Almond, B., Nielsen, R., \& Creed, W. E. D. 2014. Serving two masters: Transformative resolutions to institutional contradictions. Religion and Organization Theory, vol. 41: 301-337. Emerald Group.

Di Mauro, F., Caristi, P., Couderc, S., Di Maria, A., Ho, L., et al. 2013. Islamic finance in Europe. European Central Bank.

Durand, R., \& Jourdan, J. 2012. Jules or Jim: Alternative Conformity to Minority Logics. Academy of Management Journal, 55(6): 1295-1315.

Eisenberg, E. M. 1984. Ambiguity as strategy in organizational communication. Communication Monographs, 51(3): 227-242.

Eisenhardt, K. M., \& Graebner, M. E. 2007. Theory building from cases: Opportunities and challenges. Academy of Management Journal, 50(1): 25-32.

Essers, C., \& Benschop, Y. 2007. Enterprising Identities: Female Entrepreneurs of Moroccan or Turkish Origin in the Netherlands. Organization Studies, 28(1): 49-69.

Ferlie, E., Fitzgerald, L., Wood, M., \& Hawkins, C. 2005. The Nonspread of Innovations: the Mediating Role of Professionals. Academy of Management Journal, 48(1): 117-134.

Friedland, R., \& Alford, R. 1991. Bringing society back In: Symbols, practices and institutional contradictions. In W. Powell \& P. DiMaggio (Eds.), The New 
Institutionalism in Organizational Analysis: 232-263. Chicago ; London: University of Chicago Press.

Furnari, S. 2014. Interstitial Spaces: Micro-Interaction Settings and the Genesis of New Practices between Institutional Fields. Academy of Management Review, 39(4): 439462.

Gioia, D. A., Corley, K. G., \& Hamilton, A. L. 2013. Seeking qualitative rigor in inductive research: Notes on the Gioia methodology. Organizational Research Methods, 16(1): $15-31$.

Giroux, H. 2006. 'It was such a handy term': Management fashions and pragmatic ambiguity. Journal of Management Studies, 43(6): 1227-1260.

Glynn, M. A. 2000. When Cymbals Become Symbols: Conflict Over Organizational Identity Within a Symphony Orchestra. Organization Science, 11(3): 285-298.

Gold, R. L. 1958. Roles in Sociological Field Observations. Social Forces, 36(3): 217-223.

Granqvist, N., \& Gustafsson, R. 2016. Temporal Institutional Work. Academy of Management Journal, 59(3): 1009-1035.

Greenwood, R., Raynard, M., Kodeih, F., Micelotta, E. R., \& Lounsbury, M. 2011. Institutional complexity and organizational responses. The Academy of Management Annals, 5(1): 317-371.

Grim, B. 2016. The Role of Faith in Systemic Global Challenges. World Economic Forum.

Gümüsay, A. A. 2015. Entrepreneurship from an Islamic Perspective. Journal of Business Ethics, 130(1): 199-208.

Gümüsay, A. A. 2017. The Potential for Plurality and Prevalence of the Religious Institutional Logic. Business \& Society, 1-26.

Gümüsay, A. A. 2018. Unpacking entrepreneurial opportunities: an institutional logics perspective. Innovation: Organization \& Management, 20(3): 209-222.

Hayat, U., \& Malik, A. 2014. Islamic Finance: Ethics, Concepts, Practice. Research Foundation Literature Reviews, 9(3): 1-121.

Heracleous, L., \& Barrett, M. 2001. Organizational Change as Discourse: Communicative Actions and Deep Structures in the Context of Information Technology Implementation. Academy of Management Journal, 44(4): 755-778.

Iannaccone, L. R. 1998. Introduction to the Economics of Religion. Journal of Economic Literature, 36(3): 1465-1495.

Jarzabkowski, P., Matthiesen, J. K., \& Van de Ven, A. H. 2009. Doing which Work? A Practice Approach to Institutional Pluralism. In T. B. Lawrence, R. Suddaby, \& B. Leca (Eds.), Institutional Work: Actors and Agency in Institutional Studies of Organizations: 284-316. Cambridge: Cambridge University Press.

Jay, J. 2013. Navigating Paradox as a Mechanism of Change and Innovation in Hybrid Organizations. Academy of Management Journal, 56(1): 137-159.

Kellogg, K. C. 2009. Operating room: Relational spaces and microinstitutional change in surgery. American Journal of Sociology, 115(3): 657-711. 
Kraatz, M. S., \& Block, E. S. 2008. Organizational implications of institutional pluralism. In R. Greenwood, C. Oliver, R. Suddaby, \& K. Sahlin-Andersson (Eds.), The Sage Handbook of Organizational Institutionalism: 243-275. London: Sage.

Kreiner, G. E., Hollensbe, E., Sheep, M. L., Smith, B. R., \& Kataria, N. 2015. Elasticity and the Dialectic Tensions of Organizational Identity: How Can We Hold Together While We Are Pulling Apart? Academy of Management Journal, 58(4): 981-1011.

Langley, A. 1999. Strategies for theorizing from process data. Academy of Management Review, 24(4): 691-710.

Lawrence, P. R., \& Lorsch, J. W. 1967. Differentiation and Integration in Complex Organizations. Administrative Science Quarterly, 12(1): 1-47.

Lewis, M. W. 2000. Exploring Paradox: Toward a More Comprehensive Guide. Academy of Management Review, 25(4): 760-776.

Locke, K. 2001. Grounded theory in management research. London: Sage.

Lok, J., \& de Rond, M. 2013. On the plasticity of institutions: Containing and restoring practice breakdowns at the Cambridge University Boat Club. Academy of Management Journal, 56(1): 185-207.

Lounsbury, M., \& Glynn, M. A. 2001. Cultural entrepreneurship: stories, legitimacy, and the acquisition of resources. Strategic Management Journal, 22(6-7): 545-564.

Marquis, C., \& Lounsbury, M. 2007. Vive la résistance: Competing logics and the consolidation of U.S. community banking. Academy of Management Journal, 50(4): 799-820.

Meyer, J. W., \& Rowan, B. 1977. Institutionalized organizations: Formal structure as myth and ceremony. American Journal of Sociology, 83: 340-363.

Meyer, R. E., \& Höllerer, M. A. 2016. Laying a smoke screen: Ambiguity and neutralization as strategic responses to intra-institutional complexity. Strategic Organization, 14(4): 373-406.

Nelson, R. E. 1989. Organization-environment isomorphism, rejection, and substitution in Brazilian Protestantism. Organization Studies, 10(2): 207-224.

Nelson, R. E. 1993. Authority, organization, and societal context in multinational churches. Administrative Science Quarterly, 38(4): 653-682.

Ocasio, W., Loewenstein, J., \& Nigam, A. 2015. How Streams of Communication Reproduce and Change Institutional Logics: The Role of Categories. Academy of Management Review, 40(1): 28-48.

Orlikowski, W. J., \& Yates, J. 2002. It's about time: Temporal structuring in organizations. Organization Science, 13(6): 684-700.

Pache, A.-C., \& Santos, F. 2010. When worlds collide: The internal dynamics of organizational responses to conflicting institutional demands. Academy of Management Review, 35(3): 455-476.

Pache, A.-C., \& Santos, F. 2013. Inside the Hybrid Organization: Selective Coupling as a Response to Conflicting Institutional Logics. Academy of Management Journal, 56(4): 972-1001. 
Peifer, J. L. 2014. The institutional complexity of religious mutual funds: Appreciating the uniqueness of societal logics. Religion and Organization Theory, vol. 41: 339-368. Emerald Group.

Phillips, N., Lawrence, T. B., \& Hardy, C. 2004. Discourse and institutions. Academy of Management Review, 29(4): 635-652.

Poole, M. S., \& Van de Ven, A. H. 1989. Using Paradox to Build Management and Organization Theories. Academy of Management Review, 14(4): 562-578.

Pound, E. 1996. The Cantos of Ezra Pound. New York: New Directions.

Powell, W. W., \& Colyvas, J. A. 2008. Microfoundations of institutional theory. In R. Greenwood, C. Oliver, K. Sahlin-Andersson, \& R. Suddaby (Eds.), The Sage handbook of organizational institutionalism, vol. 840. London: Sage.

Pratt, M. G., Rockmann, K. W., \& Kaufmann, J. B. 2006. Constructing Professional Identity: The Role of Work and Identity Learning Cycles in the Customization of Identity Among Medical Residents. Academy of Management Journal, 49(2): 235-262.

Preminger, B., \& Drori, G. S. 2016. How Institutions Get Materialized in Space: "Spatialized Logics" Along Jerusalem"s Western Wall. How Institutions Matter!, vol. 48A: 101136. Emerald Group.

Purchase, S., Ellis, N., Mallett, O., \& Theingi, T. 2018. Religious Social Identities in the Hybrid Self-presentations of Sikh Businesspeople. British Journal of Management, 29(1): 99-117.

Putnam, L. L., Fairhurst, G. T., \& Banghart, S. 2016. Contradictions, Dialectics, and Paradoxes in Organizations: A Constitutive Approach. The Academy of Management Annals, 10(1): 65-171.

Quattrone, P. 2015. Governing social orders, Unfolding rationality, and Jesuit accounting practices: A procedural approach to institutional logics. Administrative Science Quarterly, 60(3): 411-445.

Raaijmakers, A. G. M., Vermeulen, P. A. M., Meeus, M. T. H., \& Zietsma, C. 2015. I Need Time! Exploring Pathways to Compliance under Institutional Complexity. Academy of Management Journal, 58(1): 85-110.

Ramus, T., Vaccaro, A., \& Brusoni, S. 2017. Institutional Complexity in Turbulent Times: Formalization, Collaboration, and the Emergence of Blended Logics. Academy of Management Journal, 60(4): 1253-1284.

Reay, T., \& Hinings, C. R. 2009. Managing the rivalry of competing institutional logics. Organization Studies, 30(6): 629-652.

Reinecke, J., \& Ansari, S. 2015. When times collide. Temporal brokerage at the intersection of markets and development. Academy of Management Journal, 58(2): 618-648.

Rossman, G. B., \& Rallis, S. F. 2003. Learning in the Field: An Introduction to Qualitative Research. SAGE.

Schad, J., Lewis, M. W., Raisch, S., \& Smith, W. K. 2016. Paradox Research in Management Science: Looking Back to Move Forward. The Academy of Management Annals, 10(1): 5-64. 
Selznick, P. 1957. Leadership in administration : a sociological interpretation. Evanston, Ill: Row, Peterson.

Sillince, J., Jarzabkowski, P., \& Shaw, D. 2012. Shaping strategic action through the rhetorical construction and exploitation of ambiguity. Organization Science, 23(3): $630-650$.

Smets, M., Jarzabkowski, P., Burke, G., \& Spee, P. 2015. Reinsurance trading in Lloyd's of London: Balancing conflicting-yet-complementary logics in practice. Academy of Management Journal, 58(3): 932-970.

Smets, M., Morris, T., \& Greenwood, R. 2012. From practice to field: A multilevel model of practice-driven institutional change. Academy of Management Journal, 55(4): 877904.

Smith, W. K. 2014. Dynamic Decision Making: A Model of Senior Leaders Managing Strategic Paradoxes. Academy of Management Journal, 57(6): 1592-1623.

Smith, W. K., \& Besharov, M. L. 2018. Bowing before Dual Gods: How Structured Flexibility Sustains Organizational Hybridity. Administrative Science Quarterly.

Smith, W. K., \& Lewis, M. W. 2011. Toward a Theory of Paradox: A Dynamic equilibrium Model of Organizing. Academy of Management Review, 36(2): 381-403.

Smith, W. K., \& Tracey, P. 2016. Institutional complexity and paradox theory: Complementarities of competing demands. Strategic Organization, 14(4): 455-466.

Smith, W. K., \& Tushman, M. L. 2005. Managing Strategic Contradictions: A Top Management Model for Managing Innovation Streams. Organization Science, 16(5): $522-536$.

Suddaby, R. 2010. Challenges for institutional theory. Journal of Management Inquiry, 19(1): 14-20.

Suddaby, R., \& Greenwood, R. 2005. Rhetorical Strategies of Legitimacy. Administrative Science Quarterly, 50(1): 35-67.

Taylor, S. J., \& Bogdan, R. 1984. Introduction to qualitative research methods: the search for meanings (2nd ed). New York: Wiley.

Thornton, P. H. 2004. Markets from culture: Institutional logics and organizational decisions in higher education publishing. Stanford University Press.

Thornton, P. H., \& Ocasio, W. 1999. Institutional logics and the historical contingency of power in organizations: Executive succession in the higher education publishing industry, 1958-1990. American Journal of Sociology, 105(3): 801-843.

Thornton, P. H., Ocasio, W., \& Lounsbury, M. 2012. The Institutional Logics Perspective: A New Approach to Culture, Structure, and Process. Oxford: OUP.

Tillich, P. 1957. Dynamics of faith. New York: Harper \& Row.

Townley, B. 2002. The Role of Competing Rationalities in Institutional Change. Academy of Management Journal, 45(1): 163-179.

Tracey, P. 2012. Religion and organization: A critical review of current trends and future directions. The Academy of Management Annals, 6(1): 87-134. 
Tracey, P. 2016. Spreading the Word: The Microfoundations of Institutional Persuasion and Conversion. Organization Science, 27(4): 989-1009.

Tracey, P., Phillips, N., \& Jarvis, O. 2011. Bridging institutional entrepreneurship and the creation of new organizational forms: A multilevel model. Organization Science, 22(1): $60-80$.

Tracey, P., Phillips, N., \& Lounsbury, M. 2014. Taking religion seriously in the study of organizations. Religion and Organization Theory, vol. 41:3-21. Emerald Group.

Washington, M., Van Buren III, H. J., \& Patterson, K. 2014. Pastor practices in the era of megachurches: New organizational practices and forms for a changing institutional environment. Religion and Organization Theory, vol. 41: 187-213. Emerald Group.

Weber, M. 1904. The Protestant ethic and the spirit of capitalism. London: Allen \& Unwin.

Weber, M. 1920. The sociology of religion. Boston: Beacon Press.

Zilber, T. B. 2011. Institutional multiplicity in practice: A tale of two high-tech conferences in Israel. Organization Science, 22(6): 1539-1559.

Zilber, T. B. 2016. How Institutional Logics Matter: A Bottom-Up Exploration. How Institutions Matter!, vol. 48A: 137-155. Emerald Group. 
TABLE 1: Data Overview

\begin{tabular}{|c|c|c|c|}
\hline Data source & $\begin{array}{c}\text { Ethnographic Observations } \\
\text { (obs) }\end{array}$ & $\begin{array}{l}\text { Interviews } \\
\quad \text { (int) }\end{array}$ & $\begin{array}{l}\text { Documentary Evidence } \\
\text { (doc) }\end{array}$ \\
\hline Data items & 60 days & 73 semi-structured interviews & 1350 documents \\
\hline Pages & 450 & 1000 & 17000 \\
\hline $\begin{array}{l}\text { Description } \\
\text { of data }\end{array}$ & $\begin{array}{l}\text { Attended executive and departmental } \\
\text { meetings, as well as meetings with field-level } \\
\text { actors like professional services firms. On-site } \\
\text { for major milestones in the licensing process. } \\
\text { In between fieldwork stays, joined conference } \\
\text { calls, received status updates via email and had } \\
\text { regular phone conversations. } \\
\text { Five extended fieldwork periods, as well as } \\
\text { several one-day and two-day visits, allowed for } \\
\text { deep ethnographic immersion, observing day- } \\
\text { to-day activities and exchanges, and partaking } \\
\text { in informal meetings and social gatherings. } \\
\text { Participated in three field-level conferences } \\
\text { with bank representatives. }\end{array}$ & $\begin{array}{l}58 \text { interviews with senior executives, managers, } \\
\text { junior staff and consultants in the project office } \\
\text { as well as } 15 \text { interviews with key field actors like } \\
\text { Islamic Finance experts, public servants and } \\
\text { potential customers throughout the entire } \\
\text { research project. Interviews lasted between } 45 \\
\text { minutes and } 2 \text { hours averaging } 60 \text { minutes. } 49 \\
\text { were recorded and transcribed. In } 24 \text { interviews } \\
\text { detailed notes were taken during and directly } \\
\text { after the interview. }\end{array}$ & $\begin{array}{l}\text { Key project documents included handbooks, } \\
\text { decision sheets and presentations for internal and } \\
\text { external use, presentations prepared for the bank } \\
\text { by (potential) suppliers, partners and consultants, } \\
\text { field-level reports, official announcements, } \\
\text { conference proceedings and books, brochures, } \\
\text { magazines, newspapers, websites, and social } \\
\text { media data such as Facebook posts and tweets. } \\
\text { Also included materials such as status updates, } \\
\text { emails, and project-related draft documents. }\end{array}$ \\
\hline $\begin{array}{l}\text { Analysis } \\
\text { insights for }\end{array}$ & Handling of organizational hybridity & Reflection on organizational hybridity & $\begin{array}{l}\text { Forming and codification of organizational } \\
\text { hybridity }\end{array}$ \\
\hline
\end{tabular}


TABLE 2: Dimensions, Themes and Data

\begin{tabular}{l}
\hline Theoretical Dimensions, \\
Themes \& Categories \\
\hline Polysemy \\
\hline 1. Conceptual \\
A. Religion regarded \\
as an integral \\
commitment \\
B. Focus on profit, \\
religion conceived as a \\
necessary requirement \\
2. Presentational \\
C. Multiple meanings \\
in artifacts and pictures \\
D. Varied purpose in \\
statements and \\
documents \\
\hline Polyphony \\
\hline 3. Spatial \\
E. Internal prayer \\
facility: ablution area \\
and masjid separate \\
from conference rooms \\
F. External prayer \\
facility: mosque
\end{tabular}

\section{Temporal}

G. Religious practices shaping business schedule and working hours

H. Celebrating religious festivities affecting work schedule

\section{Multilingual}

I. Official and informal languages

J. Multiple languages in conversations, documents and meetings

\section{Representative Data}

A1. "We have integrated Islamic values in our mission." (int)

A2. "Religion does not only have a constraining but also a recommending function. There may be products, which are actually unproblematic; but there may be products, which are better, even if the profit of the company might be somewhat affected." (int) B1. "We have utility maximization under the constraint of Islamic values." (int) B2. "And this approach of profit maximization under the auxiliary condition of Islamic rules, I believe that is a key to success for the long-term fulfillment of the whole thing. Otherwise this will be a short story." (int)

$\mathrm{C} 1$. The date tree as both a religious symbol as well as a symbol for the environment features prominently as the company logo and on promotion documents. (doc) $\mathrm{C} 2$. The color green, associated with Islam and sustainability is frequently used. (obs) D1. Selected slogan is "Islamic. Meaningful. Trading/Acting." (doc) relating to the Quran (2:275), where it says that God has permitted trade and forbidden interest. D2. Gala opening event title: "Premiere under palm trees - a special occasion bears fruits", evokes secular associations of holidays as much as religious ones. (obs)
E1. "We sometimes practice the communal prayer together and have discussions afterwards." (int)

E2. "I feel content, because I can do my Wudu (ritual ablution) and I can go to the prayer room for prayer. I do not need to render an account to anyone." (int)

F1. "Fridays, we attend Jumu'ah (congregational prayer)" (int). Others have an extended lunch or leave work earlier. (obs)

F2. "We generally have lunch before or after the Friday prayer together." (int)

G1. "We have offered our employees flexible working hours during Ramadan. Some arrive early, others later and leave accordingly." (int)

G2. When we schedule meetings in our day-to-day business, we say, OK, we need to schedule our prayer times. If we have a meeting for the whole day, we say during introduction, OK, this time is the midday prayer, this time the afternoon prayer." (int) H1. One evening during Ramadan KT Bank invited all employees for a dinner at sunset. Some also stayed longer for the congregational Tarawih prayer. (obs) H2. An email announced that the end of Ramadan (Eid al-Fitr) will be a holiday (doc)

I1. "The official business languages at KT Bank are German and English.” (int) I2. "Many conversations at KT Bank are conducted in Turkish, some in Arabic." (obs)

J1. Many books on Islamic Finance on a shelf are in Arabic or Turkish; while other books on banking and law are primarily in German, some in English. (obs)

$\mathrm{J} 2$. At a lunch-time meeting held in German one employee asks with a smile on his face and in a quiet voice another in Turkish, whether they should recite a prayer (obs)

\section{Elastic Hybridity}

\section{Inclusive}

K. Openness towards diverse positions and practices

L. Retention of staff with varying views

\section{Optional}

M. Acceptance of individual discretion

N. Choice created and offered to employees
K1. There was an agreement to disagree about the initial product portfolio. For the first phase only products that are accepted across diverse views were selected. (obs) K2. "I find it positive that we offer the possibility to fulfill religious beliefs." (int) L1. Employees expressing opposing views about the bank's strategy are kept. (obs) L2. "The diversity of German society and our potential customer base needs to be reflected in our employees." (int)

M1. The employee could speak about the bank in more or less religious terms. (obs) M2. Balance between religion and banking in company documents to a certain extent dependent on involved employees. (doc)

N1. "The prayer room is open to all faith and also anyone who just wants to use it for a break. We said that this room is open for anyone to use." (int)

N2. Trainings about Islamic Finance scheduled with voluntary attendance. (obs) 
FIGURE 1: Timeline of Study

\author{
Timeline of Study
}

Continuous Exchange with Regulatory Institutions

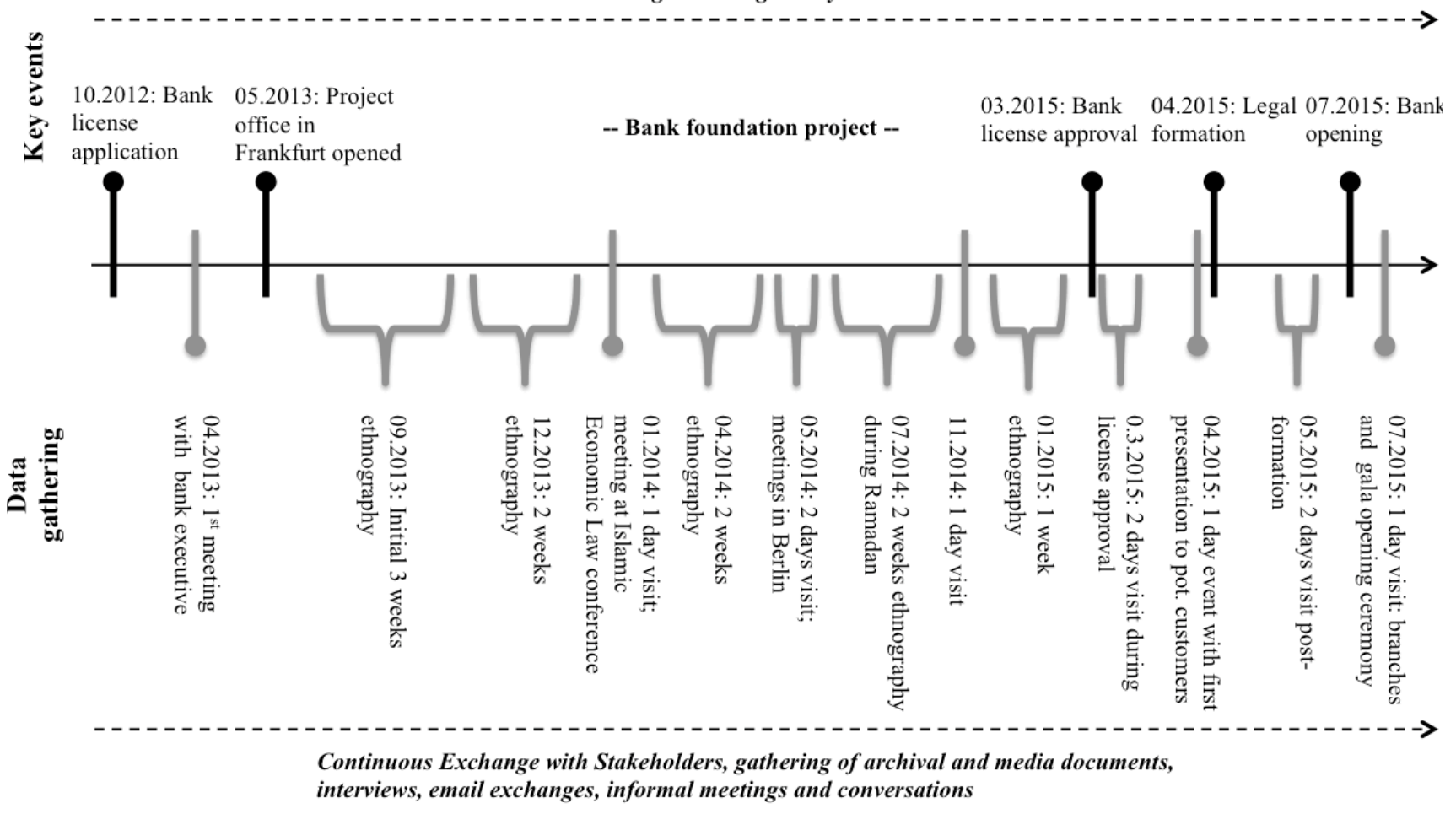

FIGURE 2: Data structure

First-order categories

Second-order themes

Aggregate theoretical dimension

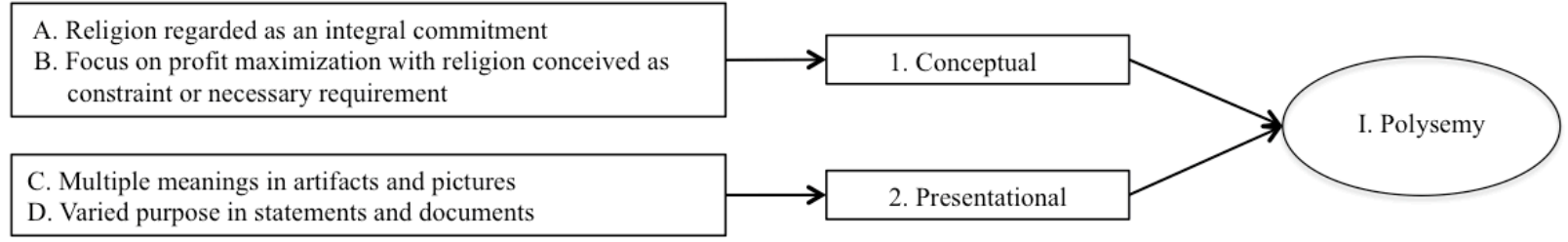

E. Internal religious facilities: ablution area and masjid separate from conference rooms

F. External prayer facility: mosque for certain congregational prayers

G. Religious practices like prayers and fasting shaping business schedule and working hours

H. Celebrating religious festivities with dinners and holidays affecting work schedule

I. Official and informal languages

J. Multiple languages in conversations, documents and meetings

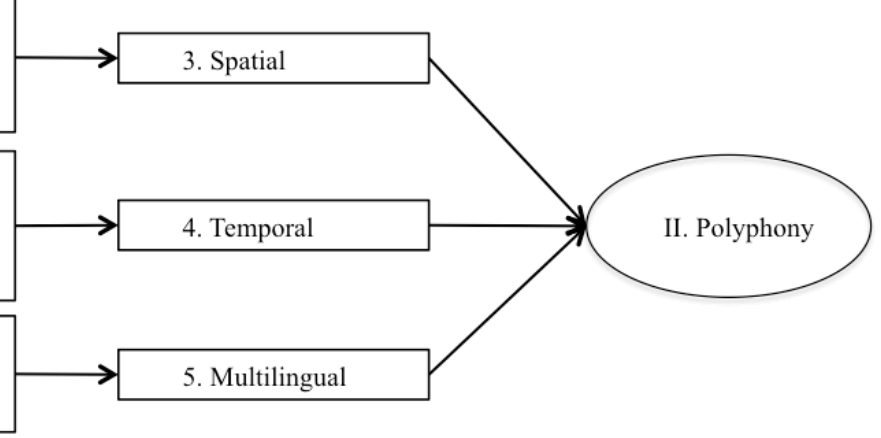

K. Openness towards diverse positions and practices L. Retention of employees with varying views

M. Acceptance of individual discretionary authority N. Choice created and offered to employees

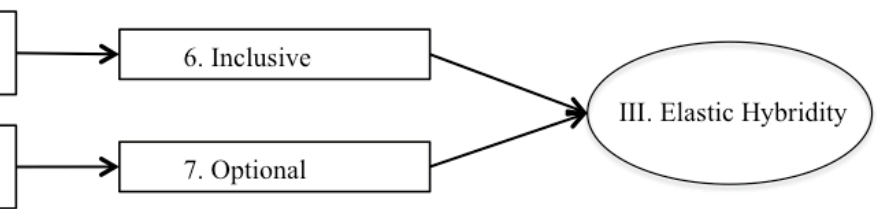




\section{Static Hybridity}

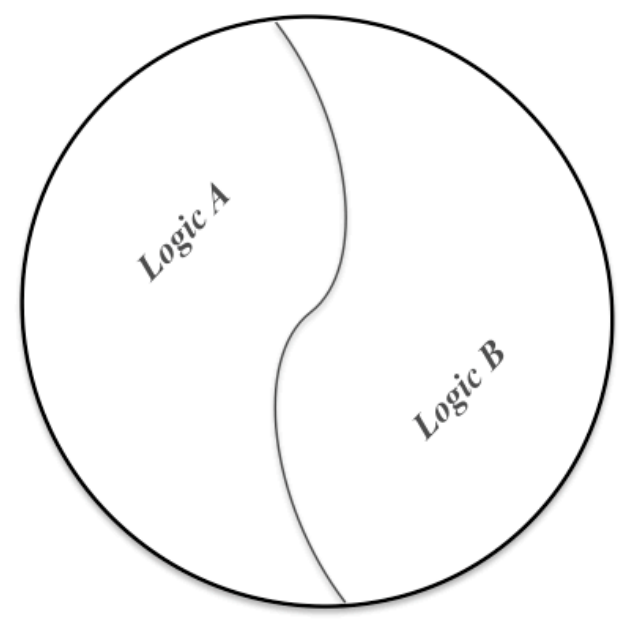

Elastic Hybridity

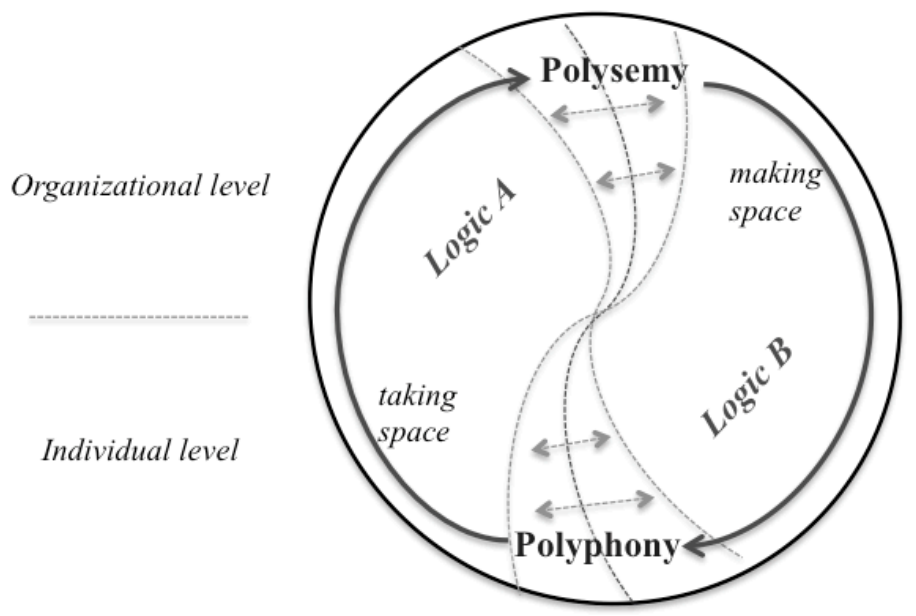

FIGURE 4: Dynamized Besharov \& Smith (2014) framework

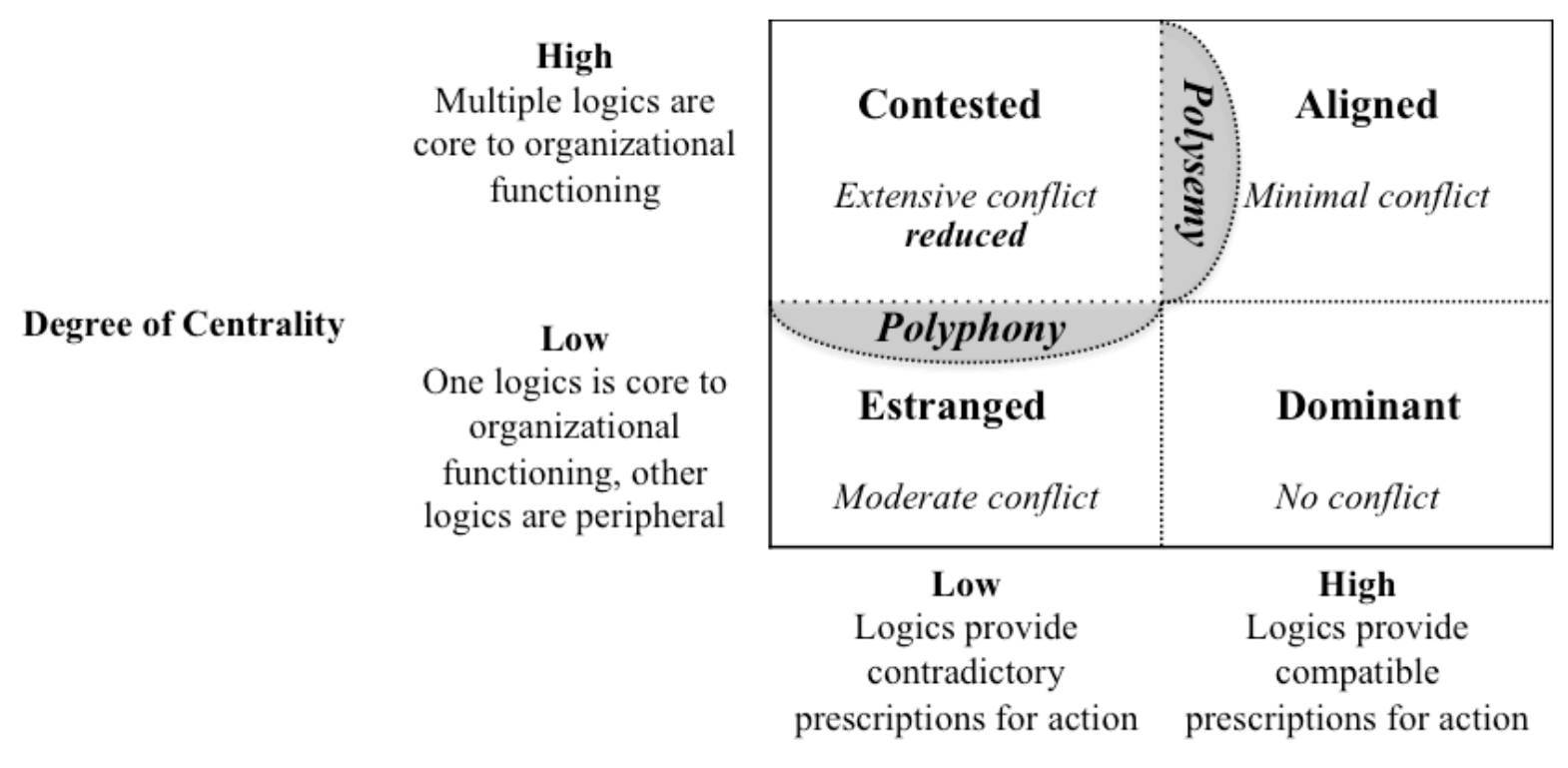

Degree of Compatibility 
Ali Aslan Gümüsay (ali.guemuesay@uni-hamburg.de) is a postdoctoral researcher at the University of Hamburg and a research fellow at Vienna University of Economics \& Business. He received his DPhil from Saïd Business School, University of Oxford, where he also was a Lecturer at Magdalen College. His research interests include institutions, values and meaning, grand challenges and new forms of organizing as well as societal complexity and engaged scholarship.

Michael Smets (michael.smets@sbs.ox.ac.uk) is an associate professor of management and organisation studies at the Saïd Business School, and a fellow of Green Templeton College, University of Oxford, from where he also received his DPhil. His research focuses on the interplay of work and institutions in professional contexts. He uses ethnographic approaches to understand how professional firms and professionals at work generate, respond to, and resolve institutional complexity.

Timothy Morris (tim.morris@sbs.ox.ac.uk) is a professor of management studies at Saïd Business School, University of Oxford. He received his Ph.D. from the London School of Economics. His research focuses on the political and structural implications of diversifying into new domains for professions and professional firms. 